\title{
Celtibérico Celtiberian
}

\author{
Francisco Beltrán Lloris \\ Grupo Hiberus | Instituto Universitario de \\ Investigación en Patrimonio y Humanidades \\ Universidad de Zaragoza \\ fbeltran@unizar.es \\ Carlos Jordán Cólera \\ Grupo Hiberus | Instituto Universitario de \\ Investigación en Patrimonio y Humanidades \\ Universidad de Zaragoza \\ cjordan@unizar.es
}

Resumen: El artículo se divide en dos partes. En la primera se ofrece una visión panorámica actualizada sobre la lengua (definición, clasificación y características) y cultura epigráfica celtibéricas (alfabetización de los celtíberos, sistemas de escritura, tipos de inscripciones, corpora). En una segunda parte, se plantean sintéticamente los retos que se presentan en un futuro inmediato en los aspectos mencionados.

Palabras clave: Celtibérico. Lengua paleohispánica. Alfabetización. Cultura epigráfica.

Abstract: The article is divided into two parts. The first offers an updated panoramic overview of the Celtiberian language (definition, classification and characteristics) and epigraphic culture (Celtiberian literacy, writing systems, types of inscriptions, corpora). In a second part, the challenges posed in the immediate future in the mentioned aspects are outlined.

Keywords: Celtiberian. Palaeohispanic language. Literacy. Epigraphic culture.

Recepción: 23.03.2020 | Aceptación: 01.04.2020

Financiación: Este trabajo se integra en el proyecto El final de las escrituras paleohispánicas (FFI2015-63981- C3-3-P), financiado por el Ministerio de Economía y Competitividad. 


\section{Visión de conjunto y estado de la cuestión ${ }^{1}$}

El celtibérico es una lengua céltica paleohispánica que se documenta epigráficamente a lo largo de las regiones interiores del nordeste peninsular atravesadas por el sistema Ibérico. A juzgar por indicios onomásticos muy consistentes, también se hablaría esta lengua o variantes próximas en las zonas ágrafas situadas más al oeste. Se han catalogado hasta la fecha más de 500 inscripciones celtibéricas, la mitad de ellas grafitos muy breves sobre cerámica, a veces de uno o dos signos. Se escribieron utilizando primero una adaptación de la escritura semisilábica ibérica levantina que empleaban sus vecinos orientales y después, una variante ligerísimamente modificada del alfabeto latino. El núcleo de las inscripciones celtibéricas procede de comarcas serranas, de economía agropecuaria y alejadas de las grandes rutas comerciales mediterráneas, vertebradas por ciudades-estado de formación reciente y escaso desarrollo urbano y monumental. Aunque existan epígrafes más tardíos y uno al menos más temprano, casi toda la producción epigráfica celtibérica se data entre mediados del siglo II y las postrimerías del I a. E. Este periodo coincide con la conquista romana de la región en el curso de las durísimas Guerras Celtibéricas que, con interludios de paz, se libraron entre 195 y 81 a. E., y a las que siguió otro episodio bélico que afectó hondamente al territorio: la Guerra Sertoriana (82-72 a. E.). Se abre después un periodo de recuperación que culmina en época de Augusto con la promoción al rango de municipio de algunas de las ciudades celtibéricas más orientales. Ya a comienzos del Principado cesa el uso escrito del celtibérico cuyos últimos testimonios seguros, grafitos sobre cerámica - algunos dudosos-, no rebasan el siglo I d. E.

En el contexto de las culturas epigráficas paleoeuropeas del Mediterráneo occidental, la celtibérica se caracteriza por una formación tardía y una duración más bien breve, de unos doscientos años. Contrasta pues con las paleohispánicas de desarrollo más temprano, como la del sudoeste hispano, breve también, pero bastante más antigua (ss. VII/VI-V/IV a. E.) o la ibérica (V a. E.-I d. E.), y, desde luego, con buena parte de las paleoitálicas empezando por la etrusca (VIII a. E.-I d. E.) y siguiendo con otras como la falisca, la mesápica, la venética, la osca o la umbra que se desarrollan a partir de los siglos

1 Este texto es una puesta al día de dos trabajos previos de características similares, convenientemente actualizados: Beltrán y Jordán 2016; 2019. La referencia a las inscripciones corresponde a la catalogación de Hesperia. Banco de datos de lenguas paleohispánicas (BDH) y, en su defecto, a Jordán 2019. 
VII, VI y V, y se extinguen entre comienzos del II, fines del I a. E. y comienzos del I d. E. (la osca) según los casos. Otras, como algunas de las sabélicas más pobremente atestiguadas - vestina, marrucina, peligna-, son de formación más tardía y aproximadamente coetáneas a la celtibérica. También se desarrollan a partir de los siglos II y I a. E. las culturas epigráficas gala y lusitana - aunque persistiendo ambas hasta pleno Principado- que coinciden con la celtibérica en ser limítrofes con las extensas regiones ágrafas que se extendían por el noroeste de Hispania, el norte y el oeste de las Galias, Britania y la región reno-danubiana que nunca utilizaron por escrito sus lenguas locales y empezaron a escribir en el Principado directamente en la lengua y el alfabeto de Roma.

Aunque la mitad de los rótulos celtibéricos sean brevísimas marcas sobre cerámica de uno o pocos signos, no es en absoluto despreciable el volumen de inscripciones con una cierta entidad: epígrafes sobre placas y láminas de bronce, téseras de hospitalidad, leyendas monetales, epitafios, rótulos sobre fusayolas, una carta sobre lámina de plomo e inscripciones rupestres, entre otras. En conjunto más de dos centenares, una cifra que sitúa a la cultura epigráfica celtibérica en una posición intermedia en el contexto paleoeuropeo: lejos sin duda de las más prolíficas y duraderas como la etrusca (+10 000), la ibérica (c. 2500) o la gala (c. 1000), ${ }^{2}$ con una duración que oscila entre los 600 y los 400 años; un poco por debajo de la mesápica — sin computar los grafitos de Grotta Poesia-, la osca o la falisca con series de entre c. 600 y 500 epígrafes producidas a lo largo de 300 o 400 años; pero comparable a la venética, la camuna o la rética (300-350), desarrolladas en periodos bastante más largos; y muy superior a las restantes, incluidas la tartésica o de la lengua del sudoeste, las sicilianas —élima, sícula-, la lusitana y la mayor parte de las sabélicas. ${ }^{3}$ Además, entre la producción epigráfica celtibérica, que muestra interesantes influencias ibéricas y sobre todo romanas, se cuentan algunos textos de enorme riqueza léxica y complejidad sintáctica como los Bronces de Botorrita, uno de los conjuntos de inscripciones más relevantes no solo de Hispania o de la Céltica antigua, sino del conjunto de las epigrafías paleoeuropeas.

Finalmente, el celtibérico, por su indiscutida condición céltica, es la única de las lenguas paleohispánicas que cuenta con una filiación clara y parientes

2 Según el reciente recuento de Mullen y Ruiz Darasse 2018, 33-37.

3 Estos datos, provisionales, sobre las culturas epigráficas paleoeuropeas se han extraído de la base de datos AELAW ( $<$ http://aelaw.unizar.es/database/languages $>$ ) y pueden contrastarse con los aportados en los diferentes capítulos de este volumen. 
conocidos así como con una morfología relativamente asequible, aunque ello, desgraciadamente, no redunde en una fácil comprensión de sus textos, todavía intraducibles salvo alguna excepción. Ocupa, además, una interesante posición en la Hispania anterior a nuestra Era no solo entre las zonas alfabetizadas - ibéricas y meridionales- y las ágrafas - el noroeste peninsular-, sino también un lugar central entre todas las lenguas paleohispánicas, pues convive en su núcleo central con las áreas ibérica y vascónica al este, confina con la lusitana al oeste y más levemente al sur con las inscripciones del sudoeste y la zona turdetana. ${ }^{4} \mathrm{Y}$ en el contexto del occidente europeo forma parte de un continuum lingüístico indoeuropeo que incluye en Hispania el lusitano $^{5}$-de celticidad discutida (Wodtko 2017) - y, fuera, las lenguas celtas de las Islas Británicas, de las Galias y de las zonas de expansión gala hacia el norte de Italia y el centro de Europa. Significativamente el paradigma tradicional, inspirado en los movimientos migratorios galos, según el cual la lengua céltica habría sido introducida en la península ibérica desde el centro de Europa en fechas relativamente tardías - II milenio a. E.- ha dado paso a una atractiva hipótesis alternativa que sitúa el solar originario de las lenguas celtas en las tierras atlánticas más occidentales de Hispania y de las Islas Británicas (Cunliffe y Koch 2010), donde por cierto están documentados el lusitano y las variantes célticas más 'arcaicas'.

\subsection{Definición y clasificación del celtibérico}

El celtibérico es una lengua indoeuropea de la familia celta. Si nos atenemos a la tradicional y de momento útil división de esta familia en Celta $\mathrm{Q}\left(<{ }^{\star} k^{w}\right)$ y Celta $\mathrm{P}\left(<{ }^{\star} k^{w}\right)$, el celtibérico pertenece al primer grupo junto con el Celta Insular Goidélico o Gaélico, con representantes como el irlandés (Irlanda), el gaélico escocés (Escocia) y la lengua de Manx (isla de Manx), desaparecida actualmente. El Celta $\mathrm{P}\left(<^{*} k^{w}\right)$, a su vez, está conformado por

4 Sobre las lenguas y las escrituras paleohispánicas véase ahora la obra colectiva dirigida por Sinner y Velaza 2019, así como las introducciones de la serie AELAW Booklets de Beltrán y Jordán 2016 (celtibérico), Moncunill y Velaza 2016 (ibérico) y Wodtko 2017 (lusitano). Para la distribución de las inscripciones paleohispánicas la cartografía suministrada por el banco de datos Hesperia (<http://hesperia.ucm.es/mapa.php $>$ ).

5 La supuesta celticidad de la mal conocida lengua del Sudoeste, defendida por algunos investigadores (Koch 2009), se asienta sobre bases muy frágiles, pues afecta a una lengua cuya identificación y estudio se enfrenta a grandes dificultades por estar redactadas en un sistema que aún no está totalmente descifrado y con scriptura continua, circunstancia que dificulta extraordinariamente la segmentación de palabras. Véase la contribución de E. Luján en este mismo volumen. 
el Celta Insular Britónico, integrado por el galés (País de Gales), el córnico (hablado hasta el s. XVIII en Cornualles) y el bretón (Bretaña francesa); y por los correspondientes parientes continentales, el galo (lengua de la Galia Cisalpina, es decir de la llanura del Po en Italia, y de la Transalpina, la actual Francia) y el lepóntico (lengua atestiguada en la región italiana de los lagos Como y Mayor). Estas dos últimas lenguas son las más cercanas al celtibérico desde el punto de vista cronológico.

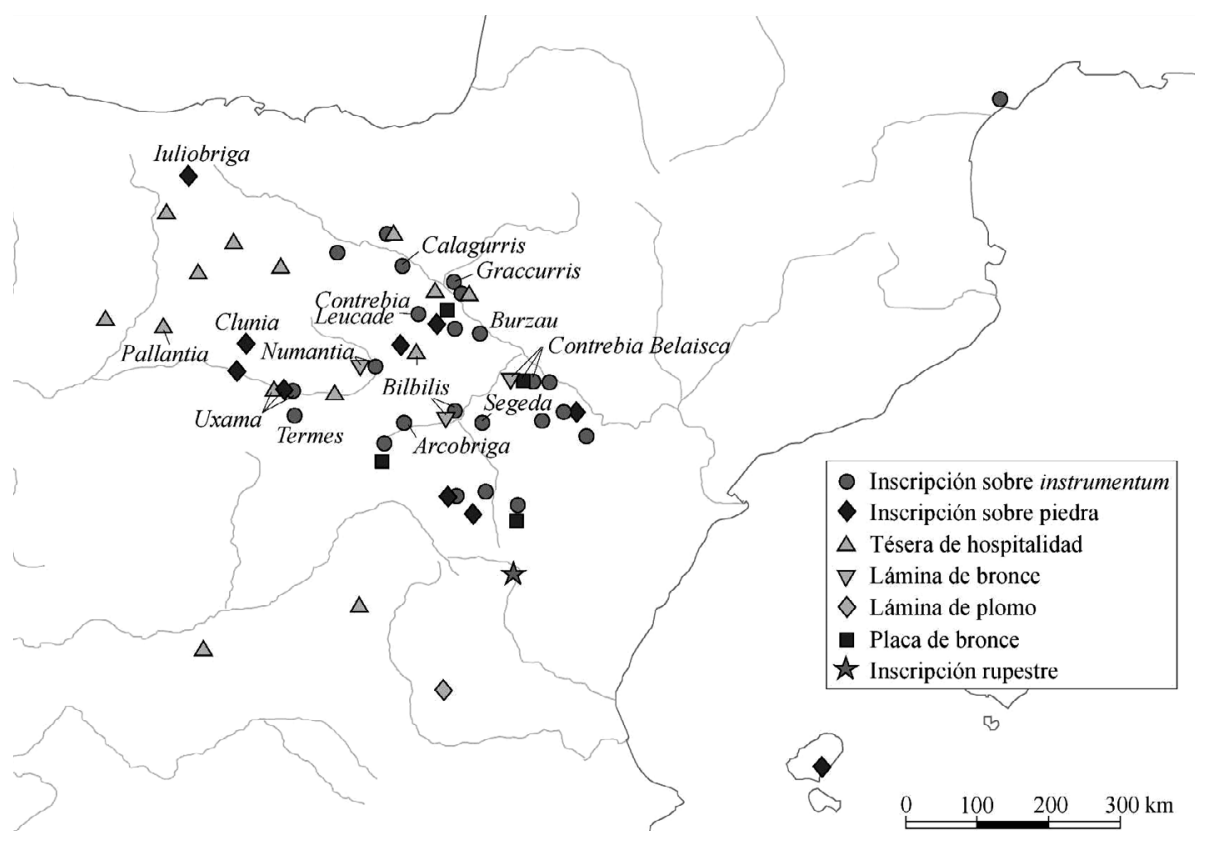

Mapa 1. Distribución de los hallazgos celtibéricos. Jordán 2018, 196.

El celtibérico es la única lengua prerromana testimoniada directamente en la península ibérica de cuya celticidad no puede dudarse. Y en este sentido quizá puedan ser equiparables los términos hispano-celta y celtibérico, como ya indicara Villar 1999, 74. Sin embargo, como ya se ha señalado y se verá a continuación con mayor detalle, la documentación indirecta deja claro que hubo hablantes de celta en otros puntos de la península ibérica. La existencia de este continuum lingüístico celta peninsular, cuyo grado de dialectalización es imposible determinar por el momento, es razón suficiente para reservar el término hispano-celta o, de manera alternativa, celta de la península Ibéri$c a$, para ese conjunto de hablas celtas hispanas y no equiparlo sin más al de celtibérico. En otras palabras, el celtibérico es hispano-celta, pero no todo el hispano-celta era celtibérico. 
Dada la naturaleza de la documentación de las lenguas paleohispánicas, lo más prudente es considerar el término "hispano-celta" con un significado, de momento y, ante todo, geográfico-lingüístico. No se puede determinar el grado de homogeneidad dialectal e, incluso, sincrónica que conformaba.

\subsection{Pueblos de lengua celtibérica}

El término de origen griego "celtíbero", literalmente "celta de Iberia", fue acuñado para designar a ciertas comunidades del interior hispano en las que los romanos reconocieron rasgos comunes con los celtas de la Cisalpina y de las Galias con los que estaban bien familiarizados. ${ }^{6}$ Se aplicó en particular a los pueblos que protagonizaron las Guerras Celtibéricas del siglo II a. E. (Untermann 1984), cuyo episodio más famoso fue el asedio y toma de Numancia (133 a. E.): esto es, Belli, Titti, Lusones y Areuaci. Ocasionalmente, también a los Pelendones - y excepcionalmente a los Vaccaei- y terminó por aludir al territorio del Sistema Ibérico comprendido entre las provincias de Cuenca y Burgos. ${ }^{7}$ El solar originario de Belos, Titos, Lusones y Arévacos - y Pelendones-, mucho más reducido, se ubicaba en el centro de esta amplia región, en las serranías y valles coincidentes con la cuenca del Jalón, y las cabeceras del Duero y del Tajo.

Sin embargo las inscripciones en lengua celtibérica se documentan también en los territorios de otros pueblos que nunca fueron considerados por los autores clásicos como propiamente celtíberos: además de los Vaccaei, Carpetani, Lobetani (?) y Turboletae (?), Olcades, Berones, Turmogi, Cantabri meridionales, e incluso entre los Vascones, en cuyas tierras parecen convivir con las lenguas ibérica y vascónica. ${ }^{8}$ Este espacio desborda hacia el norte y el oeste el Sistema Ibérico, penetrando en los territorios de otros pueblos escasamente alfabetizados o ágrafos durante los siglos II y I a. E. pero en los que existen indicios onomásticos de que utilizaban una lengua céltica similar o idéntica al celtibérico: Autrigones, Varduli y Caristii en el País Vasco, Cantabri y Astures de la cornisa Cantábrica y los pobladores de las dos Mesetas hasta las regiones portuguesas y extremeñas en las que está atestiguada epigráficamente la otra lengua paleohispánica indoeuropea: el lusitano.

6 Quizás acuñado por Fabio Píctor, vid. Pelegrín 2005.

7 Por ejemplo, Plin. Nat. 3.25 (caputque Celtiberiae Segobrigenses) y 27 (Clunia, Celtiberiae finis). Sobre los celtíberos véase, entre otros muchos trabajos, Beltrán 1989; Chaín y Torre 2005; Lorrio 2005; Burillo 2007.

8 Sobre el vascónico-aquitano, Gorrochategui e. p. 


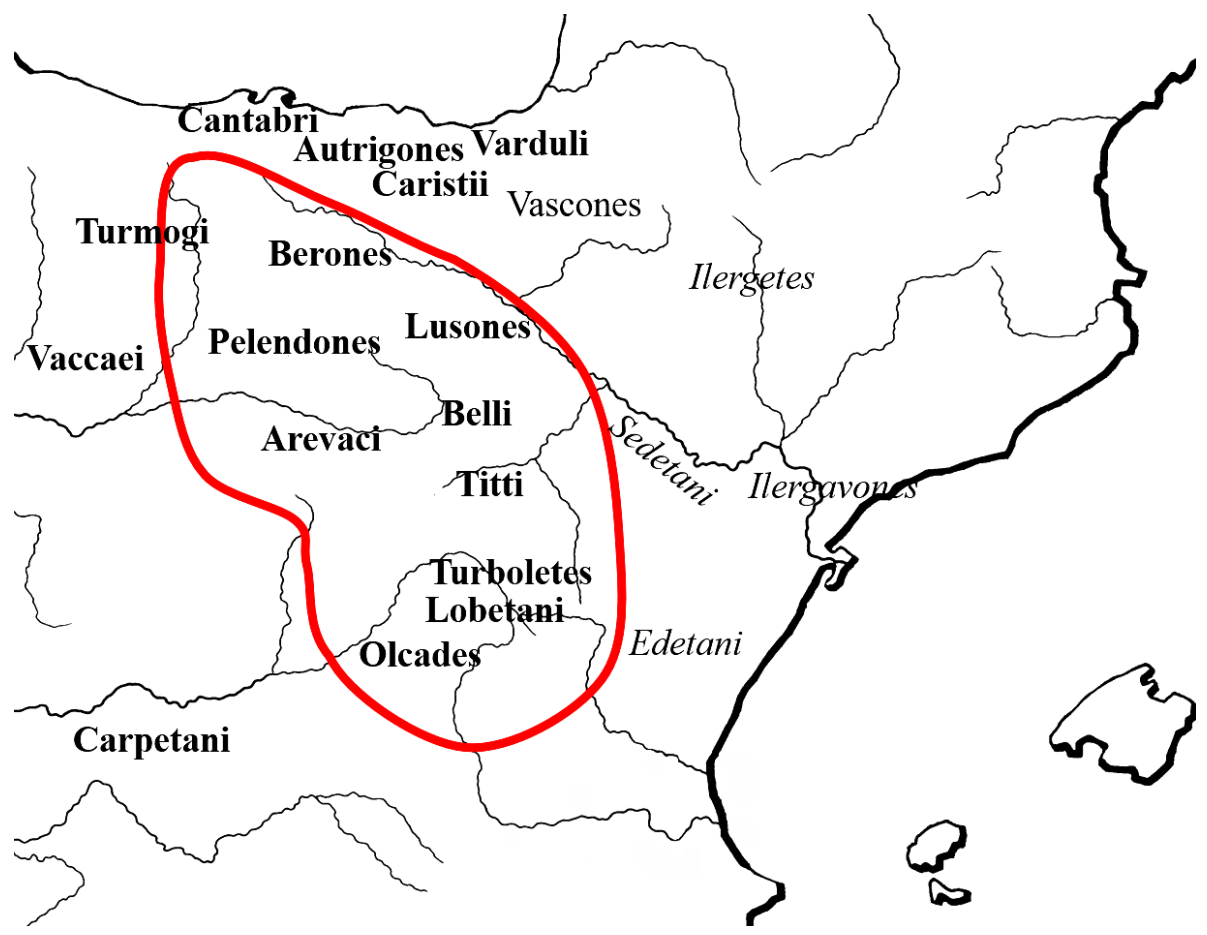

Mapa 2. Continuum epigráfico-lingüístico celtibérico e indicación de los pueblos celtófonos, iberófonos y vasconófonos.

En definitiva, el nombre de la lengua no coincide con la definición étnica del término que la denomina. A. Tovar, que fue uno de los primeros en acuñar la expresión "lengua de los celtíberos" para referirse a este idioma, no explicita las razones que motivaron esta denominación (Tovar 1946). Pero resulta claro que el término ofrecía ventajas evidentes: afectaba a pueblos en cuyos territorios aparecían esas inscripciones, era un tanto vago e incluía el término celta. Después la denominación fue popularizada por Lejeune en sus Celtiberica, que tampoco se plantea la discrepancia entre el nombre dado a la lengua y los pueblos habitualmente designados con esta denominación (Lejeune 1955), y la tradición científica posterior ha terminado por adoptarla sin mayor cuestionamiento.

\subsection{Distribución geográfica y cronología de los testimonios}

Como se ha visto, el continuum epigráfico-lingüístico celtibérico se extiende a lo largo de un territorio coincidente con el curso superior y medio del Ebro hasta Zaragoza, las cabeceras de los ríos Turia, Júcar, Guadiana y Tajo, y el curso superior y medio del río Duero, es decir con las serranías y valles 
atravesados por el Sistema Ibérico, la cadena montañosa que separa la Meseta central por el nordeste de la depresión del Ebro. También se han localizado algunos documentos fuera de este territorio: en Ibiza, en la provincia de Cáceres y en Gruissan, Francia. En algunos casos conocemos muy bien las razones de estas "excentricidades" que afectan a objetos portátiles, en otros el motivo está todavía por determinar.

Más allá de este núcleo definido por la aparición de epígrafes en celtibérico, la toponimia y también la onomástica personal y divina presente en las inscripciones latinas del Principado dibuja una amplia zona afín o compatible con el celtibérico que abarca buena parte de la Cornisa Cantábrica y las dos Mesetas, y que penetra incluso en la franja occidental de la península Ibérica, en la que no obstante se observan nítidos rasgos distintivos en la onomástica (Untermann 1965; Navarro y Ramírez 2003).

La cronología de los documentos más antiguos se sitúa a mediados del siglo II a. E., con la única excepción por ahora de la fálera inscrita (Velaza e. p.) perteneciente al tesoro de Armuña de Tajuña (Guadalajara), conjunto que habría sido enterrado en una cronología bastante anterior, concretamente en los últimos cinco años del siglo III a. E. (Ripollès, Cores y Gozalbes 2009, 171). Los testimonios más recientes llegan hasta el siglo I d. E., ${ }^{9}$ momento en el que el celtibérico desaparece del registro escrito substituido por el latín y se atestiguan también los últimos testimonios literarios del uso de la lengua como el pasaje de Tac. Ann. 4.45, referido al año 25 d. E. (Beltrán 2011). A partir de este momento su uso debió reducirse al ámbito familiar para desaparecer en los siguientes decenios: así, el poeta Marcial (40-104 d. E.), oriundo del municipio romano de Bilbilis y orgulloso de sus orígenes celtibéricos, no parece conocer ya la lengua vernácula (Beltrán 2004a).

La notable extensión del continuum epigráfico-lingüístico celtibérico y su posición central en Hispania produjeron contactos con las restantes lenguas paleohispánicas, con el latín obviamente e incluso, como se ha señalado previamente, usos esporádicos en contextos lingüísticos alejados como en el caso del epitafio de Ibiza, recuperado en un ambiente de lengua púnica. Sin embargo, al margen del latín, solo excepcionalmente se observan situaciones de multilingüismo como ocurre en la zona meridional del área vascónica y quizá

9 Jordán 2019 recoge diversos ejemplos de grafitos cerámicos que podrían datarse en el siglo I d. E. y alguno para el que se ha propuesto una fecha en el II d. E. 
también en Galicia, en donde, a juzgar por la onomástica parece convivir con una lengua similar al lusitano.

\subsection{Historiografía y estado de la cuestión. Bibliografía principal. Corpora impresos y en línea}

La identificación de la lengua celtibérica fue relativamente tardía, pues la lectura de las inscripciones redactadas en escrituras epicóricas no pudo realizarse con fidelidad hasta el desciframiento de los semisilabarios paleohispánicas por M. Gómez-Moreno en los años 20 del siglo XX, generalizado en España a partir de los años 40 y aceptado internacionalmente solo en las décadas finales del siglo XX (Untermann 1997, 358-361). Hasta ese momento dominó la teoría llamada vasco-iberista, según la cual en la península ibérica se hablaría durante la Antigüedad una sola lengua local, la ibérica, de la que descendería el vasco moderno (Von Humboldt 1821). Es cierto que la onomástica revelaba la existencia de elementos incuestionablemente célticos como los propios etnónimos Celtiberi o Celtici, o bien la nutrida serie de topónimos con final en -briga (Segobriga, Nertobriga, Conimbriga...) repartida por el centro y el occidente peninsular, pero se consideraba que los pueblos celtas que los introdujeron en Hispania se habrían disuelto lingüística y culturalmente entre la población ibérica.

El genial desciframiento de Gómez-Moreno tuvo la virtualidad de poner de manifiesto la existencia de una pluralidad de lenguas anotadas en escritura paleohispánica. Además, fue también este investigador quien, en 1942, señaló por vez primera el posible carácter céltico de algunos epígrafes (Gómez-Moreno 1949), una intuición que A. Tovar demostró incontestablemente en diversos trabajos utilizando inscripciones como los grafitos rupestres de Peñalba de Villastar (Teruel) que presentaban la ventaja de estar redactados en alfabeto latino y que le llevaron a defender la existencia de una lengua celtibérica (Tovar 1949). Pese a que investigadores de tanto prestigio como M. Lejeune - en su Celtiberica de 1955- aceptaron rápidamente las conclusiones expuestas por Tovar, la existencia de una lengua plenamente céltica en Hispania tardó un tiempo aún en ser aceptada en Europa. A ello contribuyó definitivamente el descubrimiento en 1970 del primer Bronce de Botorrita (Zaragoza), rápidamente dado a conocer y editado en 1980 por A. Beltrán y el propio Tovar (Beltrán y Tovar 1982), que resultó ser el texto más rico lingüísticamente que se conoce hasta la fecha en celta continental y demostró definitivamente que los celtas hispanos no habían perdido en absoluto su idioma, dando así carta de naturaleza científica a la lengua celtibérica. 
Pese a ello la condición céltica de los celtíberos tardó aún en imponerse plenamente en los círculos arqueológicos. Y ello porque todavía en los años 70 y 80 del siglo XX se manejaba una concepción 'culturalista' de los celtas antiguos que los identificaba con el horizonte arqueológico de La Tène y con los rasgos sociales de los galos. En esas fechas, además, todavía se entendía la presencia de celtas en Hispania como producto de un fenómeno migratorio relativamente reciente - es decir de hacia el año 1000 o poco anterior- similar al que los galos habían protagonizado en los siglos IV y III a. E. De ahí que, por ejemplo, en la magna exposición organizada en 1991 por W. Kruta en el veneciano Palazzo Grassi con el título I Celti. La prima Europa, los celtas hispanos ocuparan un lugar periférico y difícilmente integrable en la dinámica general de la obra que, pese al título, no se centraba en realidad en los celtas antiguos sino en los galos y la cultura lateniense (Kruta 1991). A diferencia de estos, los celtas hispanos de los siglos II y I a. E. no tenían druidas, ni reyes; no moraban en grandes oppida como Bibracte; no se regían por el patrón monetario oro/plata, sino que acuñaban monedas de plata y bronce; ni compartían teónimo alguno con sus vecinos septentrionales. Por el contrario, vivían en ciudades-estado gobernadas por magistrados y senados, con una fuerte relevancia de la ciudadanía como demuestran las tesserae hospitales; tenían una estructura familiar peculiar como queda reflejado en el nombre familiar hereditario; y apenas compartían rasgos materiales con la cultura de La Tène (Beltrán 1992).

La indudable celticidad de los celtíberos hispanos, puesta de manifiesto por epígrafes como los bronces de Botorrita, y sus diferencias evidentes con los galos latenienses han contribuido a precisar la noción de celta subrayando su carácter esencialmente lingüístico, al tiempo que nuevos puntos de vista cuestionan incluso el supuesto origen centroeuropeo de la lengua céltica sugiriendo una posible génesis en la fachada atlántica europea desde donde se habría difundido hacia Centroeuropa (Cunliffe y Koch 2010).

Sobre la epigrafía y la lengua celtibéricas pueden consultarse las introducciones de Beltrán y Jordán en la serie AELAW Booklets (Beltrán y Jordán 2016) y en el volumen consagrado a la Paleohispanística editado por Sinner y Velaza (2019). El corpus de referencia de la epigrafía celtibérica no monetal es el cuarto volumen de los fundamentales Monumenta Linguarum Hispanicarum, de J. Untermann 1997. La parte numismática está recogida en el primer volumen de la misma obra (Untermann 1975), junto con el de las otras lenguas paleohispánicas. A estas obras hay que añadir la edición con 
amplia introducción y comentarios lingüísticos, una completa bibliografía, e ilustraciones en algunas piezas de C. Jordán, Lengua y epigrafía celtibéricas (2019) y la versión on line actualizada de las inscripciones celtibéricas en Hesperia. Banco de datos de lenguas paleohispánicas, abierto al público en 2014 ( $<$ http://hesperia.ucm.es $>$ ). C. Jordán recoge anualmente la aparición de nuevas piezas o nuevas lecturas e interpretaciones en las Chronicae publicadas en la revista Palaeohispanica.

\subsection{La lengua: fonética, morfología y sintaxis. Léxico}

\subsubsection{Fonética y fonología celtibéricas}

La celticidad del celtibérico puede comprobarse perfectamente en el nivel fónico de la lengua, donde pueden detectarse unos rasgos específicamente celtas, es decir, rasgos que comparte solamente con las otras lenguas celtas y que confieren a esa familia carta de naturaleza propia dentro del conjunto lingüístico indoeuropeo. Estos son: el tratamiento de ${ }^{\star} \bar{o}:{ }^{\star} \bar{o}>\bar{a}$ en sílaba no final $\mathrm{y}^{{ }^{\star} \bar{o}}>\bar{u}$ en sílaba final; tratamiento $\left.{ }^{\star} r+K>r i ;{ }^{*}\right]+K>l i$ (donde $\mathrm{K}=$ oclusiva y $r, l=$ sonantes vocálicas): ${ }^{*} g^{w}>b:{ }^{*}{ }^{*}{ }^{w h}>{ }^{*} g^{w}$, paso posterior al anterior; ${ }^{*} p>$ $\varphi>\varnothing$, fricativización y pérdida de ${ }^{\star} p$ en posición inicial ante vocal o líquida e intervocálica.

El celtibérico ha sufrido transformaciones fónicas que comparte con otras lenguas indoeuropeas, caso de la igualdad en el tratamiento $\mathrm{de}^{\star} k^{w} \mathrm{y}^{\star} k w$, que presenta también el latín; la desaspiración de la serie sonora aspirada y fusión con las oclusivas sonoras, rasgo compartido con eslavo, báltico y avéstico; el resultado $\breve{a} \mathrm{de}{ }^{\star} h$ (laringal) en posición interconsonántica como ocurre también en latín, gótico, eslavo antiguo, lituano, etc.; el tratamiento ar, al, am, an (excepto en el caso ya referido), al igual que el griego para las líquidas y el griego, armenio, albanés, tocario y hetita para las nasales; el paso ${ }^{\star} \bar{e}>\bar{i}$, que también se da en armenio.

Obviamente, el celtibérico también presenta rasgos propios, que están siendo definidos poco a poco por los especialistas. El apartado que más atención está recibiendo es el tratamiento de la silbante originaria, ${ }^{*} s$, junto con el de las oclusivas dentales ${ }^{\star} d,{ }^{\star} d^{h}(\$ 2.1 .4) .{ }^{10}$

10 Un amplio tratamiento de la lengua celtibérica, con bibliografía, en Jordán 2019, 95-278. 


\subsubsection{Morfología celtibérica}

En el plano morfológico, la flexión nominal es fácilmente comprensible desde el punto de vista indoeuropeo, tal y como puede observarse en las siguientes tablas:

\begin{tabular}{|c|c|c|c|c|}
\hline SG. & $-\bar{a} / \boldsymbol{d}-$ & $-\breve{\boldsymbol{o}}$ & $-\check{1}$ & $-\check{u}$ \\
\hline N. & $\begin{array}{l}-a<^{*}-\breve{\bar{a}} \\
\text { kusta }\end{array}$ & $\begin{array}{l}-o s<{ }^{*}-\breve{o s} \\
\text { bouitos }\end{array}$ & $\begin{array}{l}-i s<{ }^{*}-\check{l} s \\
\text { kenis }\end{array}$ & --- \\
\hline A. & $\begin{array}{l}-a m<^{*}-\breve{\bar{a}} m \\
\text { toutam }\end{array}$ & $\begin{array}{l}-o m<^{*} \text {-ŏm } \\
\text { boustom }\end{array}$ & $\begin{array}{l}-i m<{ }^{*}-i m \\
\text { aratim }\end{array}$ & --- \\
\hline G. & $\begin{array}{l}-a s<{ }^{*}-\breve{\bar{a}} s \\
\text { turuntas }\end{array}$ & $\begin{array}{l}-o<{ }^{*}-\breve{o} \\
\text { aualo }\end{array}$ & $\begin{array}{l}- \text { eys }<{ }^{*} \text {-eys } \\
\text { luzeis }(?)\end{array}$ & --- \\
\hline D. & $\begin{array}{l}-a y<{ }^{*}-\breve{\bar{a}} y \\
\text { masnai }\end{array}$ & $\begin{array}{l}-u y<{ }^{*}-\bar{o} y \\
\text { ueizui }\end{array}$ & $\begin{array}{l}-e y<{ }^{*}-e y \\
\text { kenei }\end{array}$ & $\begin{array}{l}- \text { wey }<{ }^{*} \text {-wey } \\
\text { LVGVEI }\end{array}$ \\
\hline Ab. & $\begin{array}{l}-a z<{ }^{*}-\breve{\bar{a}} d \\
\text { arekorataz }\end{array}$ & $\begin{array}{l}-u z<^{*}-\bar{o} d \\
\text { usamuz }\end{array}$ & $\begin{array}{l}-i z<<^{*}-\bar{l} d \\
\text { bilbiliz }\end{array}$ & --- \\
\hline L. & $\begin{array}{l}-a y<{ }^{*}-\breve{\bar{a}} y \\
\text { kustai (?) }\end{array}$ & $\begin{array}{l}-e y<{ }^{*}-e y \\
\text { lutiakei }\end{array}$ & --- & --- \\
\hline \multicolumn{5}{|l|}{ PL. } \\
\hline N. & --- & $\begin{array}{l}-o y<{ }^{*}-o y \\
\text { stoteroi (?) }\end{array}$ & --- & --- \\
\hline A. & $\begin{array}{l}-a s<{ }^{*}-\breve{\bar{a}} n s \\
\text { listas (?) }\end{array}$ & $\begin{array}{l}-u s<- \text { ons } \\
\text { matus (?) }\end{array}$ & --- & --- \\
\hline G. & $\begin{array}{l}- \text { aum }<\times \text { *ā̄om } \\
\text { otanaum }(?)\end{array}$ & $\begin{array}{l}-u m<<^{*}-\bar{o} m \\
\text { abulokum }\end{array}$ & $\begin{array}{l}-i s u m<{ }^{*} \text {-is-ōm } \\
\text { kentisum (?) }\end{array}$ & $\begin{array}{l}-o w m<{ }^{*}-o w-\bar{o} m \\
\pm \text { DNOVM? (?) }\end{array}$ \\
\hline $\begin{array}{l}\text { D. } \\
\text { Ab. }\end{array}$ & --- & $\begin{array}{l}-u b o s<{ }^{*}-(o) b^{h} O s \\
\text { arekoratikubos }\end{array}$ & --- & --- \\
\hline
\end{tabular}




\begin{tabular}{|c|c|c|c|c|}
\hline SG. & $-n$ & $-r$ & $-n t$ & resto ocl. \\
\hline N. & $\begin{array}{l}-u<{ }^{*}-\bar{o} n \\
\text { melmu }\end{array}$ & $\begin{array}{l}-r<*(V) r \\
\text { kar }\end{array}$ & --- & $\begin{array}{l}{ }^{*}-K+s \\
\text { teiuoreikis (?) }\end{array}$ \\
\hline A. & --- & --- & $\begin{array}{l}-a m<{ }^{*}-n t-m \\
\text { tirikantam }\end{array}$ & --- \\
\hline G. & $\begin{array}{l}-(u) n o s<{ }^{*}-(V) n-\check{s} s \\
\text { melmunos }\end{array}$ & $\begin{array}{l}-(e) r o s<{ }^{*}-(V) r-\breve{s} s \\
\text { tuateros }\end{array}$ & $\begin{array}{l}-o s /-e s<^{*}-n t-o s /-e s \\
\text { tirikantos } \\
\text { steniotes }\end{array}$ & $\begin{array}{l}-o s<{ }^{*}-K-\breve{o s} \\
\text { tokoitos }\end{array}$ \\
\hline D. & $\begin{array}{l}-(u) n e y<*(V) n-e y \\
\text { terkininei }\end{array}$ & --- & $\begin{array}{l}-\bar{e}<^{*}-e y \\
\text { STENIONTE }\end{array}$ & $\begin{array}{l}-e y<{ }^{*}-K-e y \\
\text { tokoitei }\end{array}$ \\
\hline Ab. & $\begin{array}{l}-(u) n e z<{ }^{*}(V) n-\breve{e} d \\
\text { oilaunez }\end{array}$ & --- & --- & $\begin{array}{l}-e z<{ }^{*}-K-\check{e} d \\
\text { sekobirikez }\end{array}$ \\
\hline L. & --- & --- & --- & --- \\
\hline \multicolumn{5}{|l|}{ pl. } \\
\hline N. & --- & $\begin{array}{l}-(e) \text { res }<{ }^{*}-(v) r-e s \\
\text { tuateres }\end{array}$ & --- & $\begin{array}{l}-e s<^{*}-K-\breve{e s} \\
\text { aleites (?) }\end{array}$ \\
\hline A. & --- & --- & --- & --- \\
\hline G. & --- & --- & --- & --- \\
\hline $\begin{array}{l}\text { D. } \\
\text { Ab. }\end{array}$ & --- & $\begin{array}{l}-r u b o s<{ }^{*} r(o) b^{h} o s \\
\text { matrubos }\end{array}$ & --- & --- \\
\hline
\end{tabular}

Tablas 1 y 2. Solo se han expuesto los datos correspondientes a los animados. En cuanto a los inanimados solo se tienen datos para el N.A. sg. y el plural de los temas en -o, cuyas terminaciones son -om (boustom puede ser un ejemplo de ello) y - $a$, ajustándose en todo a lo esperado.

El celtibérico presenta una característica en la morfología nominal que lo hace único en el panorama de las lenguas indoeuropeas. Se trata del genitivo singular de los temas en - $o$, que termina en - $o$, en lugar de la esperada terminación celta (e itálica) $-\bar{\imath}$.

Otro rasgo que individualiza al celtibérico, ahora frente al resto de las lenguas celtas, es el caso ablativo (Villar 1996; Jordán 2019, 182-186). Aquí va de la mano de lenguas como el hetita, indio antiguo, avéstico, latín y osco-umbro. Además, utiliza un recurso muy similar a ellas para marcarlo, la adición $\operatorname{de}^{*}-d$ tras una vocal, y los datos apuntan a que se daba en todos los temas. También presenta locativo del singular, seguro en los temas en - $o$ y probable en los temas en - $a$. Más que dudosa es la existencia de un instrumental. ${ }^{11}$

11 Para el singular de los temas en -o, Villar 1993-1995; 2005, 325. Para los temas en - $a$, sg. y pl., Prósper 2008, 49-55; 2011. 
El adjetivo mejor atestiguado en celtibérico es, sin duda, el denominativo de tres terminaciones con sufijo -ko-, también de clara raigambre indoeuropea, ${ }^{12}$ ya que es el más utilizado en la formación de los nombres de los grupos familiares, elemento fundamental en la fórmula onomástica celtibérica, como se verá después $(\$ 1.7)$. Este sufijo puede presentar las siguientes modalidades, ordenadas de mayor a menor frecuencia de aparición: -iko-; -oko-; -sko-; -ako-; -ioko-; -nko-; -iako-; -uko-; -rko-; -aiko-; -eko-; -ieko-. ${ }^{13}$ También se tienen ejemplos de otros sufijos indoeuropeos, como -yo-, -o-, -no-, -ro-, -lo-.

Todavía no se ha encontrado una forma indiscutible de un adjetivo en grado comparativo, sin embargo, hay una serie de palabras que parecen presentar una formación de superlativo en las modalidades ${ }^{*}{ }^{\circ} m o-(o-m m o-)$; ${ }^{*}$-(i)s- ${ }^{\circ}$ mo- (o -is-momo-): VERAMOS [TE.17.18] de * uper-, en VIROS VERAMOS = 'uir supremus'; usama [SO.06.02, -2] de *(o)ups- 'arriba'; sekisamos [MON.69]: sobre ${ }^{\star}$ sego- 'victoria' = 'el muy victorioso'. El celtibérico presenta en este caso una formación muy cercana, si no igual, al latín.

La manera más fácil de detectar formas verbales personales celtibéricas es, sin duda, fijarse en las desinencias. ${ }^{14} \mathrm{El}$ análisis de las formas permite afirmar que en celtibérico no se da la distinción del celta insular entre la flexión absoluta y la conjunta, sino que sigue el más genuino patrón indoeuropeo de desinencias primarias frente a secundarias para indicar tiempo presente frente a tiempo pasado. ${ }^{15} \mathrm{Y}$ así se detectan formas verbales con desinencia ${ }^{\star}$ - $t i, 3^{\text {a }}$ p. sg. primaria activa, como ambitiseti [Z.09.01, A-5], relacionado etimológicamente con ambitinkounei [Z.09.01, A-6], posible infinitivo; formas verbales con desinencia ${ }^{*}-t, 3^{\mathrm{a}}$ p. sg. secundaria en las que ${ }^{*}-t$ se transformaría en $-\theta$, que en la escritura se reflejaría con sigma $<\mathbf{z}>$, como terberez [SP.02.08, B-4]; formas verbales con desinencia ${ }^{*}-n t i 3^{\mathrm{a}} \mathrm{p}$. del pl. primaria, voz activa, como aranti [Z.09.24, A-4]; una forma verbal con desinencia ${ }^{\star}-n t 3^{a} p$. del pl. secundaria, voz activa, podría ser atibion [Z.09.24, A-5]. La forma más clara como expresión de la diátesis es auzanto [Z.09.03, 01], con desinencia ${ }^{\star}$-nto $3^{\mathrm{a}}$ p. del pl. secundaria, voz media, $c f$. auzeti; y quizá esianto [SP.02.08 A-2]. La existencia de otras personas es ya más problemática de probar.

12 Cf. Villar 1995a, 121-152; Villar et al. 2001, 155-190; Rubio 2001.

13 Vid. Villar y Jordán en Villar et al. 2001, 174, para diferentes tablas y resultados.

14 En Wodtko 2000; Jordán 2004; Rubio 2013; Jordán 2019 se encuentra la mayoría de las referencias bibliográficas para este apartado.

15 Cf. Gorrochategui 1994, 319-323; Villar 1997, 933; 2005, 338-346. 
Cuestión más compleja es identificar morfemas verbales que sirvan para expresar otras categorías verbales como el tiempo exacto (por ejemplo, futuro), el modo (indicativo, subjuntivo, optativo e imperativo) o el tema aspectual (tema de presente, aoristo o perfecto). De todas estas categorías quizá las mejor identificadas sean unas formas de imperativo, que se consideran tales precisamente por la aparición de una desinencia -tuz $<{ }^{*}$-tōd, como bizetuz [Z.09.01, A-5] ( cf. latín -tōd >-tō). También hay varias formas con una posible marca de subjuntivo - $\bar{a}$-. Más discutidas son unas posibles marcas -s- (¿futuro?, ¿ subjuntivo?) o -bi- (¿futuro?).

En las formaciones consideradas verbales también se detectan preverbios, como ambi-, kom-, es-, ro-, ter-, to-, ti- y uer-, pero no parece que tengan, por el momento, otra función que la propia semántica de matizar el significado del teórico verbo sin el preverbio.

La nómina de formas verbales puede cerrarse con los posibles nombres verbales o infinitivos en -unei (sin consenso para la explicación de su origen), como el ya indicado ambitinkounei; con los participios o adjetivos verbales de carácter pasivo en -to-, como litom [Z.09.01, A-1 y A-2 (x3)]; con un posible participio de presente AVDINTVM [Bronce de Novallas, -5] (Jordán 2014a); y con una posible formación de gerundio o gerundivo en -nd-, DVNDOM, en el mismo documento [-3] (Jordán 2015).

En el campo pronominal, no se ha detectado hasta el momento ninguna forma personal segura. Sí en cambio hay formas de los temas ${ }^{*}$ so-, ${ }^{\star} t o-\mathrm{y}^{*}$ sto-, sin que puedan determinarse por el momento posibles relaciones interparadigmáticas: so [GU.01.01, -3], N. o G.sg.m.; sa [GU.01.01, -7], N.sg.f.; soz [Z.09.01, A-2], N.sg.n. < ${ }^{*}$ sod; SAM [Bronce de Novallas, 7], A.sg.f.; soisum [Z.09.03, 02]: G.pl.m. o n.; saum [Z.09.01, A-8] < ${ }^{*}$ sa-ōm, G.pl.f.; somei [Z.09.01, A-8] < ${ }^{\star}$ so-(s)m-ei, L.sg.m. o n.; somui [Z.09.01, A-7] < ${ }^{\star} s o-(s) m-\bar{o} i$, D.sg.m. o n.; tas (G.sg.f., un N.pl.f. o un A.pl.f.) [Z.09.24]; sdam [GU.01.01, -6], A.sg.f., y stena [Z.09.01, A-3, -6].

El celtibérico optó por el tema ${ }^{*}$ yo/ye para conformar su pronombre relativo: ios [Z.09.01, A-10], [Z.09.24, A-7], N.sg.m.; ia [Z.09.03, 01], N.sg.f. o N.A.sg.n.; iom [Z.09.01, A-5, A-7, A-10], [Z.09.24, B-4], posible A.sg.m.; ias [Z.09.01, A-8], A.pl.f.; iomui [Z.09.01, A-7], ¿ D.sg.m.? El otro tema utilizado en las lenguas indoeuropeas como relativo ${ }^{*} k^{w} e / k^{w} o,{ }^{*} k^{w} i$ (cf. latín qui, quae, quod) podría estar en la formación de [SP.02.08, A-1] kuekuetikui, que parece un D.sg., de una formación del tipo latino quisquis, osco pispis, het. kuiškuiš. También parece ser un indefinido oskuez [Z.09.01, A-3 y -4], aunque aquí el análisis es más controvertido. 
Las palabras que tienen aspecto de numerales son kantom [Z.09.01, A-4] 'cien', tiris [Z.09.01, A-6] 'tres' y sues [Z.09.01, A-5] 'seis'. La palabra que hay consenso en considerar como adverbio es sua [Z.09.01, A-1] < ${ }^{*}$ swā, de la raíz ${ }^{*}$ swe-/swo, 'de esta forma, así. En [Z.09.24, A-1] aparece entor en el sintagma entorkue toutam 'y la población de dentro', mejor que 'dentro de la población' (Villar y Jordán en Villar et alii 2001, 119-129).

Dentro de las otras clases de palabras, las hay fácilmente reconocibles, como las preposiciones eni, preposición de dativo; entara [Z.09.01, A-9],

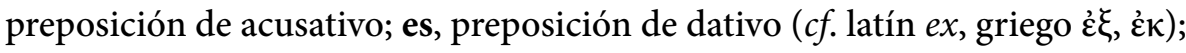
DV: preposición de dativo, $<{ }^{\star} d \bar{o}$. Conjunciones y partículas son: $-\mathbf{k u e}<{ }^{*}-k^{w} e$ : conj. copulativa enclítica; ekue [TE.03.01, -8, -9, -10] y ECQVE [Bronce de Novallas, -4] < ${ }^{\star} e t-k^{w} e$; ne, conjunción-partícula negativa y nekue; -ue $<{ }^{*} w e$, conjunción disyuntiva enclítica; y uta: conjunción copulativa no enclítica, $c f$. védico $u t a$. Y por fin entre los prefijos y adverbios pueden contarse: ambi- < ${ }^{*} m b i<{ }^{*} h_{20} n-b h^{\prime}$ 'alrededor de', $c f$. sc. $a b h i$, gr. ả $\mu \varphi$ í, lat. $a m b$-, am-, etc.; are-l arei-: la forma are- puede proceder de ${ }^{*} p^{o} r i-{ }^{*}{ }^{*} p r h i ;$ kom- $c f$. lat. cum; eni-; es- $<{ }^{*} e g^{h}{ }$ - 'de, desde'; oi- $c f$. gr. ö $\pi \mathrm{\sigma} \sigma \varepsilon \varepsilon v$, lat. $o b$; ro- $<{ }^{*}$ pro-, $c f$. sc. prá, gr. $\pi \rho o ́$, lat. pro; ti- $c f$. lat. $d \bar{e}$; uer- $c f$. gr. vi $\pi \varepsilon \rho$, lat. $s$-uper; us- $<^{*} u k s-<^{*} u p s-$ 'arriba'.

\subsubsection{Léxico}

Dada la naturaleza de los textos celtibéricos, los antropónimos y los topónimos son las palabras más numerosas en su corpus. Entre ellos hay nombres que poseen una etimología oscura y los hay que responden a una etimología indoeuropea, más o menos extendida por las lenguas de la familia y con más o menos raigambre dentro del mundo celta. Si nos fijamos en los apelativos, conocemos palabras cuyas etimologías presentan diferentes grados de certidumbre. Dentro del vocabulario familiar, hay consenso general en aceptar que kentis / gentis significa 'hijo'; kenis / genis podría ser la palabra para 'familia'; 'tuatir en sus formas de genitivo del singular, tuateros, y nominativo del plural, tuateres, quizá designase a la 'hija'; y launi a la 'esposa'. En el léxico institucional y jurídico aparece kar / CAR, cuyo significado se debate entre 'amistad, pacto' y 'tessera'; kortika / gortika, podría ser la palabra para 'pública', aunque habrá que revisar este punto debido a la aparición de PVBLICVS en el bronce de Novallas; el término dureita / DVREITA es oscuro; tirikantam podría hacer referencia a un concepto espacial; bintis parecía una palabra para designar un tipo de magistrado, pero su posible relectura como 
kentis no puede rechazarse sin más; y ueizos podría estar haciendo referencia a un 'testigo' (vid. Wodtko 2000; Jordán 2019, 240-278).

\subsection{Las inscripciones}

\subsubsection{Cultura epigráfica}

Como se ha señalado al comienzo, la Celtiberia y su entorno cultural conforman desde la perspectiva de la escritura un espacio de transición entre el litoral ibérico, alfabetizado tempranamente en el curso del siglo $\mathrm{V}$ a. E., y las regiones más occidentales y atlánticas de la Hispania Citerior, también de lengua céltica a juzgar por la onomástica, que permanecieron ágrafas hasta comienzos del Principado y empezaron a escribir directamente en alfabeto y lengua latinas, sin que haya constancia, por el momento, de que utilizaran por escrito su lengua vernácula con la sola excepción de los escasos -y más tardíos- epígrafes en lengua lusitana procedentes del centro de Portugal y de la Extremadura española.

En la Celtiberia, con la excepción de la fálera de Armuña de Tajuña que parece remontarse a los últimos años del siglo III a. E. (\$ 1.2), los primeros documentos escritos aparecen en el curso del siglo II a. E., es decir coetáneamente a la penetración de las tropas romanas en la región a comienzos de esa centuria, y, por lo tanto, con tres siglos de retraso respecto de las primeras inscripciones ibéricas de la costa mediterránea. A juzgar por el temprano recurso a ciertos tipos epigráficos de matriz inequívocamente latina, como las tesserae hospitales o las placas de bronce de formato medio o grande - de los que no hay constancia en el territorio de lengua ibérica-, la cultura escrita romana ejerció una clara influencia en la epigrafía celtibérica. Sin embargo, el hecho de que hasta bien entrado el siglo I a. E. la escritura dominante en la región fuera una variante ligeramente modificada del semisilabario nordoriental pone de manifiesto también un claro componente ibérico en la alfabetización de la Celtiberia que se manifiesta igualmente en el recurso ocasional a tipos epigráficos ibéricos característicos como en el caso de la carta sobre lámina de plomo de Cuenca (La Manchuela), [CU.00.02].

De hecho, la llegada de la escritura a la Celtiberia se inserta en el triple fenómeno de intensificación en el uso de la escritura, de expansión geográfica hacia el interior y de diversificación tipológica que experimenta la epigrafía ibérica a partir del siglo II a. E. Entre sus rasgos más destacados hay que señalar la aparición de inscripciones monumentales dirigidas a una pública contemplación, prácticamente inexistentes con anterioridad, que parecen 
responder a una tendencia propia de la cultura epigráfica romana de la época. Esta tendencia cuajó con particular intensidad en núcleos costeros como Emporion (Ampurias), Tarraco (Tarragona), Saguntum (Sagunto) o Carthago Nova (Cartagena) que albergaban sociedades muy abiertas, con una clara presencia de emigrantes itálicos y romanos, y con frecuencia multilingües como en el caso de Emporion, en donde conviven griego, ibérico y latín, o Tarraco, con presencia de las dos últimas lenguas (Beltrán 2005; 2012).

En comparación con la costa mediterránea el desarrollo de la epigrafía pública y de la cultura escrita en general fue mucho menos intenso y dinámico en las regiones ibéricas del interior y, más aún, en la Celtiberia y su entorno, en donde el volumen de la documentación apenas alcanza los dos centenares de epígrafes de una cierta entidad. A esta cifra hay que añadir tres centenares más de grafitos sobre vasos cerámicos - muchos de ellos monolíteros o meras marcas geométricas no grafemáticas- y las leyendas monetales, consistentes en el nombre de la comunidad emisora, producidas en medio centenar de cecas. En conjunto, los epígrafes celtibéricos suman en torno al medio millar de documentos (Beltrán y Jordán 2016; Jordán 2019). La cronología de este corpus, muy difícil de fijar con precisión, abarca, con la excepción señalada de la fálera de Armuña, desde mediados del siglo II a. E. hasta el siglo I d. E. (Jordán 2019, 356-357), con un uso creciente a partir del siglo I a. E. del alfabeto latino, en el que, según se ha descubierto recientemente, se introdujeron algunas modificaciones epicóricas como la destinada a marcar la segunda sibilante mediante un trazo horizontal diacrítico en la parte inferior de la $\mathrm{S} .{ }^{16}$

El corpus epigráfico celtibérico, pese a su relativa modestia, ofrece muchos elementos de interés. En primer lugar y desde un punto de vista lingüístico, ofrece un material comparativo valiosísimo para el estudio de las lenguas célticas y, en particular, de las más antiguamente atestiguadas, las llamadas continentales — galo y lepóntico-. Contribuye a su conocimiento con algunos de los textos más largos y complejos desde el punto de vista sintáctico como son los documentos sobre placas de bronce de formato medio y grande procedentes sobre todo de Contrebia Belaisca (Botorrita) [Z.09.01; Z.09.03; Z.09.24] así como otros, relativamente largos también, sobre láminas de bronce de tamaño más reducido, sobre lámina de plomo — un solo caso- o esgrafiados sobre paredes rocosas. Desde la perspectiva epigráfica cuenta con géneros tan característicos como las tesserae hospitales, de las que conocemos 
no menos de una treintena con seguridad genuinas, que gracias a su semejanza con las tesserae hospitales romanas en las que se inspiran y a la frecuente aparición sobre ellas de nombres personales y de ciudades permiten una interpretación bastante aproximada de su contenido y función (Beltrán, Jordán y Simón 2009). Añádanse a estos documentos una docena de epitafios sobre piedra, unas 65 leyendas monetales diferentes y esgrafiados sobre cerámica de notable interés como, por ejemplo, los realizados sobre instrumentos textiles como las fusayolas (Beltrán, Jordán y Simón e. p.).

El uso de la escritura sobre soportes duros en la Celtiberia presenta además algunos rasgos muy singulares. Frente a los grandes núcleos del litoral mediterráneo antes mencionados, en las ciudades de la Celtiberia, con un desarrollo urbano muy limitado con la única excepción de Contrebia Belaisca, la epigrafía pública monumental no llegó a arraigar (Beltrán y Jordán 2008): apenas conocemos una docena de epitafios sobre piedra correspondientes a enterramientos individuales, grabados normalmente sobre estelas y aislados, salvo en Clunia (Peñalba de Castro) de donde proceden tres piezas y El Pueyo (Belchite), en donde se han hallado dos fragmentos. Sin embargo, sí existen documentos públicos, inscritos sobre placas de bronce de formato mediano y grande que sin duda estaban destinadas a ser expuestas: el conjunto más conocido es el ya mencionado de Contrebia Belaisca, al que se puede añadir ahora el bronce fragmentario en alfabeto latino de Novallas. Existe acuerdo general en considerar estos documentos como textos normativos emanados de las autoridades cívicas, es decir textos de carácter oficial. Lo mismo puede decirse de una gran parte de las tesserae hospitales que con seguridad alude a pactos contraídos con ciudades, aunque en este caso, dado el pequeño tamaño de los soportes, deben ser considerados documentos que no estaban destinados obviamente a una exposición pública. Si a los documentos sobre placas de bronce y las tesserae hospitales añadimos las leyendas monetales, emanadas igualmente de las autoridades ciudadanas, resulta que una parte notable de la epigrafía celtibérica, incluidos algunos de sus tipos más característicos, era de carácter oficial, un hecho que contrasta abiertamente con la epigrafía ibérica, en la que, al margen de las monedas, no se ha conseguido hasta el momento identificar epígrafes emanados de las autoridades.

Desde el punto de vista geográfico no se observan áreas epigráficas diferenciadas dentro del territorio celtibérico, pues sus tipos más característicos -las inscripciones sobre placas y láminas de bronce, y las tesserae hospitales- se distribuyen por toda la región y lo mismo ocurre con los epitafios 
sobre piedra, si bien dentro de esta clase de inscripciones sí pueden observarse ciertas tendencias locales como las estelas decoradas en Clunia o los epitafios sobre losas con interlíneas entre los renglones de la zona más oriental. Sí se observa, a cambio, una oposición en los tipos de escritura, perceptible sobre todo en los signos correspondientes a las nasales que difieren en las áreas más occidentales ('tipo Luzaga') respecto de las más orientales ('tipo Botorrita').

En resumidas cuentas, la epigrafía celtibérica se muestra como una práctica con características propias, de baja intensidad, poco orientada a la exhibición pública y con una marcada presencia de las autoridades cívicas, en la que se pueden identificar tanto referentes ibéricos - en la escritura sobre todo, pero también en el uso de ciertos tipos epigráficos como los epitafios con líneas de pautado o la carta sobre lámina de plomo- cuanto romanos, particularmente visibles en las inscripciones oficiales sobre placas de bronce y las tesserae hospitales, de bronce también, que hacen de este metal, casi desconocido como superficie de escritura en el ámbito ibérico, uno de los soportes más característicos de la epigrafía celtibérica.

A diferencia de las epigrafías ibérica y, sobre todo lusitana, en la que existen inscripciones bilingües (Estarán 2016) no ocurre lo mismo con la celtibérica, pese al perceptible impacto que en ella tuvo la cultura escrita latina. Así lo pone de manifiesto la adopción del bronce como soporte, de tipos epigráficos como las téseras de hospitalidad o las placas de bronce con textos normativos, pero también del empleo del alfabeto latino en una treintena de inscripciones o la incorporación de particularidades como la abreviación de la palabra 'hijo', ke(ntis), en la filiación onomástica, a semejanza sin duda de $f($ ilius) en la epigrafía latina. Sí que se detecta a cambio uno de los escasísimos ejemplos del empleo de palabras latinas en préstamo entre las lenguas paleohispánicas como es el caso de la palabra publicus.

Dadas las dificultades que plantea la datación precisa de los materiales epigráficos celtibéricos y su periodo relativamente corto de desarrollo doscientos años-, resulta muy difícil esbozar siquiera una evolución de la práctica epigráfica. Entre los materiales más antiguos, además de la fálera de Armuña, hay que mencionar algunas de las emisiones monetales y también grafitos sobre cerámica como los de Segeda que se pueden fechar a mediados del siglo II a. E. Mucho más difícil es precisar la cronología de las téseras de hospitalidad, las láminas y las placas de bronce que, en cualquier caso, parecen perfectamente desarrolladas en torno 100-80 a. E. Entre las producciones más recientes deben contarse los epígrafes realizados en alfabeto latino que 
deben datarse a partir de la segunda mitad del siglo I a. E. y que en muchos casos como el bronce de Novallas, los grafitos rupestres de Peñalba de Villas$\operatorname{tar}$ [TE.17] o las trullae de Termes [SO.05.01 y 02] hay que datar en época augústea o a comienzos del Principado. Una cronología tardía hay que adjudicar también a las inscripciones en escritura paleohispánica que muestran redundancia vocálica, significativamente procedentes de las áreas más occidentales, burgalesas en concreto, del continuum epigráfico celtibérico.

\subsubsection{Número de inscripciones según el tipo de soporte}

La composición actual del corpus epigráfico celtibérico según el material del soporte es:

I. Sobre cerámica: c. 400 epígrafes.

a) c. 350 sobre recipientes de cerámica de diferente tipología. Solo c. 8 $\%$ presenta cierta información lingüística reseñable.

b) 41 epígrafes sobre elementos relacionados con la actividad textil: pondera y fusayolas.

II. Sobre piedra: 58 epígrafes.

a) 13 epitafios ( 12 en escritura paleohispánica y 1 en alfabeto latino).

b) 19 sobre elementos arquitectónicos (en escritura paleohispánica). 15 de ellos parecen marcas de cantero (?) sobre fustas de columnas y otros elementos procedentes de Contrebia Belaisca.

c) 2 sobre proyectiles de catapulta (en escritura paleohispánica).

d) 22 inscripciones rupestres ( 2 en escritura paleohispánica y 20 en alfabeto latino).

e) 2 sobre bloques de piedra de función desconocida.

III. Sobre metal: 129 epígrafes.

a) 65 leyendas monetales (47 cecas).

b) 1 carta sobre plomo (en escritura paleohispánica).

c) 6 objetos de plata: 3 téseras (en escritura paleohispánica; 2 de ellas dudosas), 1 recipiente (en escritura paleohispánica) y 2 trullae (en alfabeto latino). 
d) 57 objetos de bronce: 40 téseras (9 dudosas): 31 en escritura paleohispánica y 9 en alfabeto latino. 7 láminas completas y tres fragmentos (en escritura paleohispánica). 5 placas (4 en escritura paleohispánica y 1 en alfabeto latino). 1 plato y otros 2 objetos de difícil clasificación.

\subsubsection{Tipos epigráficos}

\section{a) Leyendas monetales}

Las leyendas monetales constituyen uno de los tipos epigráficos más autónomos dentro de la cultura escrita paleohispánica, pues la emisión de moneda responde a una motivación específica de carácter fiscal y económico, regulada además por las autoridades provinciales romanas. De hecho, hay áreas como el noroeste del valle medio del Ebro que presentan una elevada actividad numismática, pero que, a cambio, apenas han producido inscripciones sobre otros soportes. No obstante, en el caso de las cecas celtibéricas su distribución geográfica coincide a grandes rasgos con la dispersión de las restantes inscripciones.

Desde el punto de vista numismático las emisiones en lengua celtibérica comparten las tendencias generales del resto de las cecas de la Hispania Citerior: incluyen series en plata y en bronce que siguen los patrones del sistema monetario romano, y muestran, en las caras que convencionalmente denominamos anverso y reverso, una cabeza viril y un jinete respectivamente, si bien a diferencia del área ibérica las cabezas suelen ser barbadas - y no imberbesy el jinete, portador de una lanza u otro tipo de arma frente a las ibéricas en las que el caballero exhibe frecuentemente una palma (Beltrán 2004b).

Las emisiones más antiguas datan de la primera mitad del siglo II, caso por ejemplo de las de sekeiza [MON.78], y como el resto de las amonedaciones en lengua vernácula parecen cesar hacia mediados del siglo I a. E. En comparación con las acuñaciones en lengua ibérica o con las producidas en el noroeste del valle medio del Ebro las leyendas celtibéricas son más simples, pues a diferencia de aquellas suelen presentar una leyenda principal en el reverso - la cara en la que figura el jinete-consistente en el nombre de la comunidad emisora, expresado sea mediante el topónimo - p. ej. sekeiza [MON.78] - sea mediante el gentilicio - p. ej. ekualakos [MON.63] - que suele aparecer abreviado en la otra cara - p. ej. se y e, respectivamente- No presentan a cambio ni marcas de valor ni nombres de magistrados ni otra clase de leyendas. 

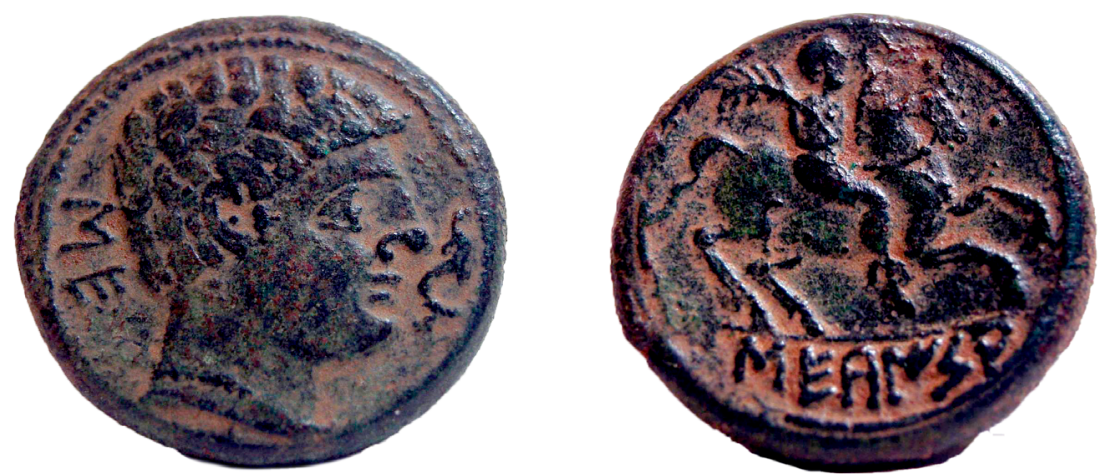

$\overline{\text { Fig. 1. As de Segeda, [MON.78]. Anverso: se. Reverso: sekeiza (foto: BDH). }}$

\section{b) Inscripciones monumentales sobre piedra}

Las inscripciones monumentales sobre piedra constituyen el tipo más característico de la cultura epigráfica que a partir del siglo II a. E. y por influencia romana, según todos los indicios, se desarrolla en el litoral mediterráneo. En lo que respecta a la epigrafía en lengua ibérica predominan claramente los epígrafes funerarios que en los grandes núcleos portuarios (Emporion, Tarraco, Saguntum) se graban sobre losas o placas que formarían parte de monumentos de una cierta entidad, mientras que en los núcleos secundarios y en el interior suelen grabarse sobre estelas, a menudo decoradas, que no suelen conformar conjuntos numerosos y que con frecuencia son hallazgos aislados (Beltrán 2012a).

La situación en el área celtibérica se asemeja a la del interior ibérico, pero con una intensidad menor, pues apenas se conoce una docena de inscripciones sobre piedra frente al centenar largo en lengua ibérica (Simón 2013). Este hecho, por sí mismo, pone de manifiesto la debilidad de la expresión epigráfica de orientación pública en la Celtiberia (Beltrán y Jordán 2008), un fenómeno que a todas luces se relaciona con la limitada monumentalización de los núcleos urbanos celtibéricos — de la que las inscripciones sobre piedra son un elemento más-, pero que podría ser indicativo también de un menor grado de alfabetización o de un menor interés por parte de las elites sociales -que son las que producen este tipo de monumentos- por singularizarse ante la comunidad por este conducto.

Significativamente, uno de los epitafios celtibéricos más relevantes, el de tirtanos abulokum letontunos ke(ntis) belikios [IB.01.01], es decir 'Dirtano, 
hijo de Letondón, de la (familia de) los Abulocos, de Beligio', procede de un área muy alejada de la Celtiberia como es la isla púnica de Ibiza, si bien presenta características formales como es una maquetación cuidada del texto con líneas de pautado en el interlineado que remiten no solo a epitafios ibéricos del Maestrazgo (p. ej. en La Iglesuela del Cid, Teruel, [TE.19.01-03]), sino también a piezas procedentes del área celtibérica limítrofe, en la que se suele localizar Belikiom (hacia Azuara, Zaragoza), como los fragmentos recientemente aparecidos en El Pueyo (Belchite) (Rodríguez y Diez 2014; 2018).

Del otro extremo de la Celtiberia, de Clunia (Peñalba de Castro, Burgos), procede la única concentración de epitafios conocida en la región. Se trata de tres estelas discoideas decoradas con escenas de guerreros, de las que existen otras varias anepígrafas, en las que el epitafio, brevísimo, ocupa un lugar marginal en relación con las imágenes [BU.06.01-02; Gorrochategui 2014]. Un buen ejemplo de este grupo es la que reza simplemente kaabaarinos [BU.06.01], correspondiente al nombre del difunto levemente esgrafiado entre las patas del caballo que monta un jinete: la repetición de la vocal tras los signos silábicos se interpreta como un influjo del sistema de escritura alfabético y se entiende como un indicio de una datación reciente (siglo I a. E.). Rasgos semejantes presenta la que exhibe el nombre mukuukaaiau [BU.06.02] (Simón y Gorrochategui 2018).

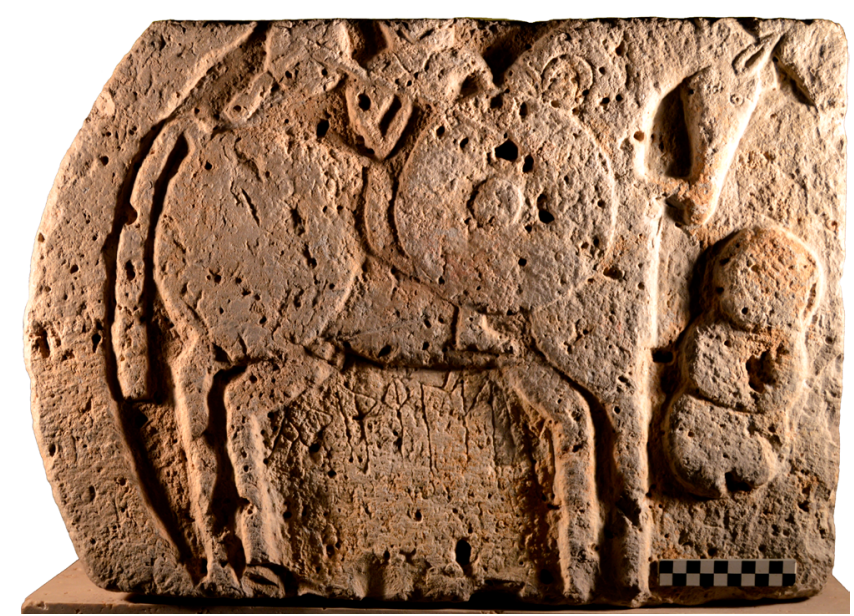

Fig. 2. Estela discoidea, procedente de Clunia, [BU.06.01]. Lectura: kaabaarinos (foto: I. Simón). 
Otras inscripciones sobre piedra proceden de Torrellas (Zaragoza [Z.01.01]), perdida, — con una fórmula onomástica compleja-, Langa de Duero (Soria [SO.04.01]), Trébago (Soria, [SO.02.01]) o El Pedregal (Guadalajara, [GU.06.01]), esta última con una sola palabra de interpretación discutida [---]karbizka[---]. A estos hay que añadir el epitafio en alfabeto latino de Retortillo (Santander, [S.01.01]), en el área limítrofe con Cantabria.

\section{c) Grafitos rupestres}

Una mención especial merece el conjunto de una veintena de rótulos levemente esgrafiados en alfabeto latino sobre la pared rocosa del santuario a cielo abierto de Peñalba (Villastar, Teruel [TE.17]), conviviendo con grafitos en lengua latina que, como los celtibéricos, parecen datar del tránsito del siglo I a. E. al I d. E. Aparte de la llamada 'Gran Inscripción' [TE.17.03], se trata de textos más bien breves consistentes en fórmulas onomásticas simples (Beltrán, Jordán y Marco 2005).

Aunque realizadas sobre piedra y ubicadas en un lugar frecuentado, estas inscripciones difícilmente pueden ser integradas entre los epígrafes de carácter público y monumental por muy diversas razones. En primer lugar por ser de tamaño reducido generalmente - hay alguna rara excepción como GVANDOS COTIRIQVM [TE.17.19], de $70 \mathrm{~cm}$ de longitud-y de visibilidad limitada como queda bien ilustrado por la llamada 'Gran Inscripción' [TE.17.03], cuyas siete líneas ocupan un área de $17 \times 42 \mathrm{~cm}$ con letras de una altura que oscila entre 0,6 y $2,5 \mathrm{~cm}$, ubicadas además a ras de suelo, condiciones estas en las que la lectura resulta imposible si no es agachado y muy de cerca.

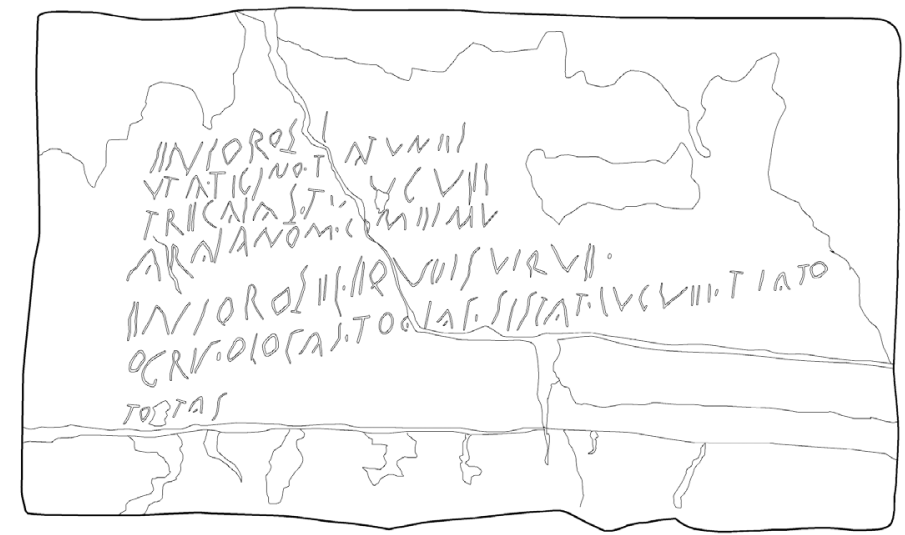

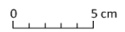

Fig. 3. Gran Inscripción de Peñalba de Villastar [TE.17.03] (dibujo: M. C. Sopena). 
Al margen de este último epígrafe, sobre cuyo contenido cultual hay acuerdo generalizado, los restantes rótulos celtibéricos se limitan a comprobar la presencia en el lugar de visitantes, algunos de los cuales parecen haber grabado su nombre varias veces (CALAITOS, GVANDOS, TVRROS), indicando quizá que los esgrafiados fueron realizados en un periodo relativamente breve de frecuentación. El empleo del alfabeto latino, así como la convivencia con epígrafes en la lengua de Roma y datables en fecha augústea, son rasgos indicativos de una datación tardía.

\section{d) Inscripciones sobre placas y láminas de bronce}

Las inscripciones sobre bronce son sin duda los tipos más característicos de la epigrafía celtibérica, un rasgo que se acentúa si se toma en consideración que este metal apenas fue utilizado por los iberos como soporte epigráfico.

Este tipo de inscripciones, en realidad y más allá del recurso al bronce como soporte, incluye dos géneros de documentos de carácter muy distinto desde la perspectiva de la cultura epigráfica, las inscripciones sobre placas de formato mediano y grande, por una parte, y las realizadas sobre láminas de pequeño tamaño que no superan los $15 \times 16 \mathrm{~cm}$ [GU.01.01], por otra. Los primeros son documentos destinados a ser expuestos públicamente, mientras que los segundos pueden ser calificados de privados.

d.1) Los epígrafes sobre placas de bronce se reducen por el momento a cuatro: los tres 'Bronces de Botorrita' [Z.09.01 = BBI: 10,5 x 40,5 cm; Z.09.03 = BBIII: 52 x 73; Z.09.24 = BBIV: $(13,7) \times(15,9)]$ y el bronce fragmentario de Novallas $((18.1) \times(22.5))$ en alfabeto latino (Beltrán et alii 2013; Jordán 2014a; 2014b; 2015).

Aunque no exista acuerdo sobre el contenido preciso de estos textos, sí hay una coincidencia general en considerarlos como documentos normativos emanados de las autoridades ciudadanas y, por lo tanto, resulta difícil no concluir que se inspiran en modelos romanos. De hecho, las inscripciones sobre placas de bronce constituyen el soporte típico para la exhibición solemne y perdurable de las decisiones adoptadas por el senado, las asambleas y los magistrados de Roma (Beltrán 1999). No deja de ser significativo que, precisamente, en Botorrita (Zaragoza), la antigua Contrebia Belaisca, se haya localizado una placa de bronce, la llamada Tabula Contrebiensis (CIL I ${ }^{2}$ 2951a) con una sentencia judicial sancionada por el gobernador de la provincia, $C$. Valerius Flaccus, en 87 a. E., es decir en el mismo horizonte cronológico que se atribuye a los bronces celtibéricos, y dotada de perforaciones para su ex- 
hibición. También BBIII, maquetada en columnas como los grandes bronces romanos, presenta un orificio para su suspensión (Beltrán, De Hoz y Untermann 1996).
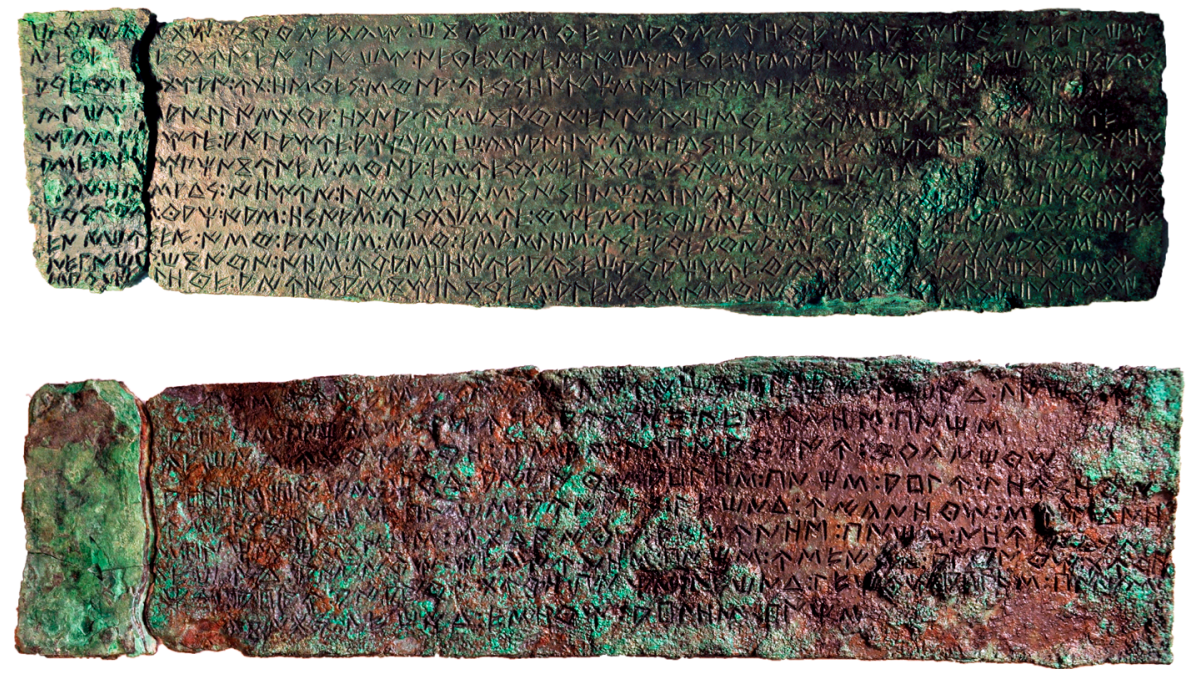

Fig. 4. Primer bronce de Botorrita (Contrebia Belaisca) [Z.09.01].

Arriba, cara A; abajo, cara B (fotos: B. Díaz).

Llama particularmente la atención que, siendo Contrebia Belaisca una ciudad destruida y abandonada hacia los años 70, que ha sido excavada en extensión y que ha proporcionado uno de los escasos conjuntos monumentales conocidos en Celtiberia compuesto por un edificio en adobe de cinco naves precedido por un porticado en columnas toscanas, no se haya localizado hasta la fecha ni una sola inscripción monumental sobre piedra, pero sí, a cambio, esas tres placas de bronce destinadas a una exhibición pública como pone de manifiesto en particular BBIII, un documento de proporciones notables $(52 \mathrm{x}$ $73 \mathrm{~cm}$ ). Resulta igualmente llamativo que, frente a la carencia en la ciudad de monumentos epigráficos públicos individuales, la cara $\mathrm{B}$ de $\mathrm{BBI}$ presente un listado de catorce individuos y que el cuerpo de BBIII, distribuido en tres columnas, exhiba un listado de dos centenares y medio de personas. La falta de proclividad hacia la autorrepresentación individual de las elites contrebienses contrasta vivamente con la inclusión de estos listados en documentos públicos y con la fijación en espacios públicos de decisiones oficiales, aunque, por el momento, la interpretación precisa de estas complejas relaciones entre público y privado, oficial y particular no resulte transparente (Beltrán y Jordán 2008). 


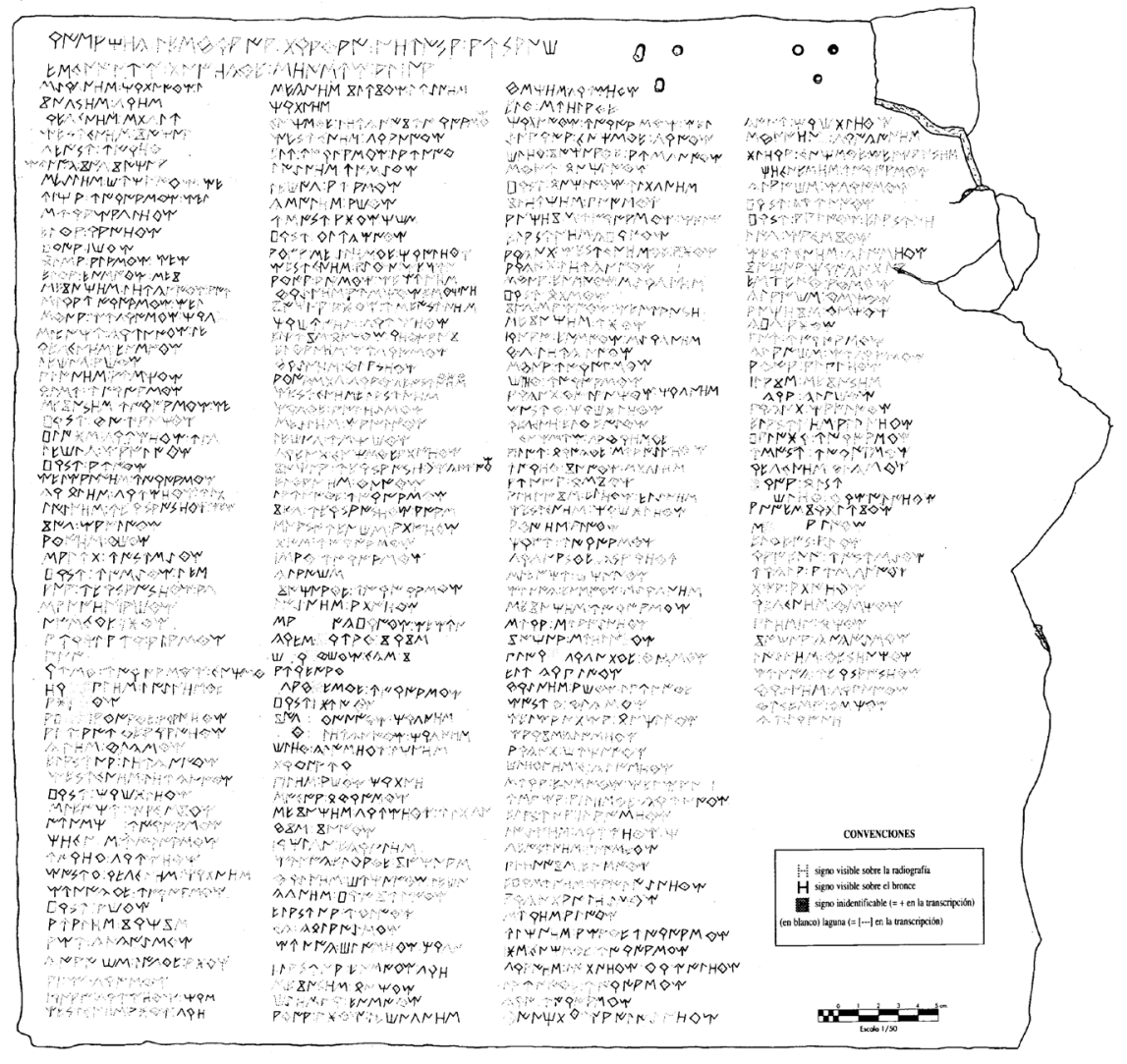

Fig. 5. Dibujo del tercer bronce de Botorrita (Contrebia Belaisca) [Z.09.03] (Beltrán et al. 1996).

d.2) Las inscripciones sobre soportes broncíneos de menor tamaño son también características de la epigrafía celtibérica, aunque remiten a un ámbito comunicativo privado, pues no parecen destinadas a una contemplación pública y en consecuencia parecen más vinculadas a las prácticas de la escritura común que a las de la escritura exhibida.

En este grupo se incluyen piezas de pequeñísimo tamaño como la laminita de Numancia de 1,5 x $5,2 \mathrm{~cm}$ con las palabras muko · kaiko [SO.01.01], de función ignorada, o la de procedencia desconocida, de 1,8 x 1,9 y con un orificio destinado aparentemente a su fijación, con las palabras letontu / auz $\cdot$ soz, interpretadas como un texto de donación del objeto al que estaría fijada por parte de un Letondón [SP.02.04]. También hay objetos mayores, como el fragmento de una posible placa de cinturón o aplique reaprovechado como superficie de escritura de $9,3 \times(5,5)$ con un texto muy incompleto, procedente de Contrebia Belaisca [Z.09.02]. 
Entre las láminas, algunas presentan textos de una cierta longitud como el "bronce de Cortono" [SP.02.03] o el "bronce de Luzaga" [GU.01.01], con cinco y siete líneas de texto, o más largos aún como el de Torrijo del Campo (Teruel) [TE.03.01], con once líneas, o el llamado "bronce Res", de autenticidad discutida, con trece líneas repartidas por sus dos caras [SP.02.08]. Aunque la interpretación de estos textos es incierta, en varios de ellos se han apreciado indicios que los clasificarían como documentos oficiales, caso de los términos relacionados con la práctica del hospitium en el "bronce de Cortono", asociados a dos ciudades en el "bronce de Luzaga", y otros menos claros en las demás piezas, aunque no se pueda excluir su condición de documentos redactados por particulares.

\section{e) Tesserae hospitales}

Las tesserae hospitales son objetos de pequeño tamaño realizados en bronce que adoptan normalmente una forma figurada - generalmente zoomorfa - y que presentan en una de sus caras una inscripción, aunque haya también ejemplares anepígrafos (Beltrán, Jordán y Simón 2009; Simón 2013). Constituyen el tipo más característico de la epigrafía celtibérica tanto por su elevado número - se conocen más de treinta piezas de autenticidad seguray su dispersión homogénea por todo el territorio cuanto por la singularidad de este género de inscripciones de claro origen romano que no solo son desconocidas en el resto de Hispania - por ejemplo en el área de lengua ibérica-, sino que en Celtiberia muestran la mayor concentración de toda la cuenca occidental del Mediterráneo, que es el ámbito en el que este tipo de epígrafes está comprobado.

El modelo de estos epígrafes es claramente romano (Beltrán 2001; 2018). De hecho, se trata de un género de epígrafe del que solo hay constancia en la Italia romana y en sus áreas de influencia, incluyendo dos piezas procedentes del sur de Francia y de Sicilia — esta de marfil- y redactadas en griego que datan de los siglos II-I a. E., cuando estos territorios dependían ya de Roma. El único precedente reseñable lo ofrecen siete piezas, también figuradas pero de marfil, realizadas en el ámbito etrusco hacia el siglo VI -algunas, en particular las de Murlo, de identificación como téseras discutible- y que, por lo tanto, no llegan a enlazar con las cuatro piezas de bronce romanas conocidas en Italia que datan de los siglos II y I. Fuera de Italia y de los dos ejemplares en griego mencionados, es Hispania el área de mayor concentración, pues de la península ibérica proceden, además de una pieza anepígrafa de marfil hallada 
en la ciudad púnica de Baria, siete con texto latino y las más de treinta piezas celtibéricas (Beltrán 2010b; Beltrán et al. 2020).

Las cuatro téseras latinas de Italia, todas datables entre el siglo III y mediados del II a. E., son objetos de bronce en forma de cabeza de carnero o de delfín que recogen muy escuetamente los nombres de los contrayentes del pacto, salvo la tessera de Fundi que presenta un texto más largo y articulado. En dos casos solo aparece una de las partes (CIL $\mathrm{I}^{2} 23$ y 828), mientras que en otros dos figuran ambas. Los contrayentes romanos parecen, todos ellos, de extracción senatorial o al menos los nombres y la cronología de las piezas hacen verosímil está identificación. En lo que respecta a los dos ejemplares que mencionan a ambos contrayentes, uno muestra el pacto entre un romano, $T$. Manlius T.f., y un noble marso, T. Staiodius N(umeri) f. (CIL I $\left.{ }^{2} 1764\right)$, mientras que el otro, de texto mutilado, vincula a un romano de nombre fragmentariamente conservado y la ciudad de Fundi (CIL I ${ }^{2}$ 611), que, además de contraer un pacto de hospitium, parece acogerse a la protección del romano en calidad de patronus, aunque este término no aparezca mencionado.

Las inscripciones latinas de Italia, por lo tanto, recogen dos tipos de acuerdo: uno de mero hospitium, es decir un acuerdo privado entre dos individuos que se comprometen a rendirse mutuamente una serie de servicios como el hospedaje, y otro que implica un hospitium público que, a juzgar por ciertas referencias literarias, suponía la concesión de ciertos privilegios por parte de la ciudad al individuo, entre los que destaca la ciudadanía honoraria.

Las tesserae hospitales latinas de Hispania presentan algunas novedades respecto de sus modelos itálicos. Estas piezas, de difícil datación, parecen escalonarse entre comienzos del siglo I a. E. y los primeros decenios de la centuria siguiente y pueden dividirse en dos grupos: las téseras figuradas que presentan escuetamente el nombre de uno de los contrayentes y las realizadas sobre láminas de forma rectangular y bordes sinuosos - en un caso en forma de cerdo- con textos más largos que implican a una ciudad y registran a los dos contrayentes. En todos los casos comprobables, uno de los contrayentes es un hispano de lengua céltica. Las primeras, de formulario unilateral, mencionan a un ciudadano romano (CIL $\mathrm{I}^{2}$ 3465, provincia de Teruel; HEp 3, 1993, 373, Fuentes Claras, Teruel) o a un indígena (CIL I ${ }^{2} 2825$, Cáceres el Viejo) acompañado de referencias al hospitium o a la tessera hospitalis. Hay además una pieza sobre lámina de bronce de bordes sinuosos relativa a la ciudad de Caurium (Coria, Cáceres), representada por un magistratus de nombre vernáculo, Turus, bien comprobado por ejemplo en Peñalba de Villastar. Las de formulario 
bilateral datan todas ellas de comienzos del Principado y están realizadas sobre láminas de bordes sinuosos o, en un caso, en forma de cerdo, y proceden de la provincia de Palencia. Dos de ellas, procedentes de Paredes de Nava, registran el pacto entre una ciudad y un individuo, en un caso Palantia, representada por un magistratus, y un Intercatiensis llamado Acces Licirni $f$. (CIL II 5763) y en el otro entre la ciudad de Intercatia y el ciudadano de Turiaso, M. Titius Fronto. Ambas recogen referencias al hospitium y la segunda, establece además que Fronto disfrute de los mismos ius y lex que los Intercatienses (AE 1999, 922). Esta concesión de los derechos cívicos aparece todavía más clara en la tessera en forma de cerdo de Herrera de Pisuerga, una pieza opistógrafa del año $14 \mathrm{~d}$. E., que recoge por sus dos caras el mismo pacto desde la perspectiva de uno y otro contrayente: la ciudad, de ubicación desconocida, de Maggauia y el ciudadano de Cusabura, ciudad también sin localizar, Amparamus Nemaio$q(u m)$, quien además de establecer un pacto de hospitium recibe explícitamente la ciuitas honoraria de Maggauia (AE 1967, 239; Beltrán 2012b).

Esta larga digresión sobre las tesserae hospitales latinas permite establecer un marco interpretativo adecuado para las tesserae celtibéricas, pues los documentos latinos proceden de la misma zona y datan de la misma época que los celtibéricos, y, además, no solo afectan a contrayentes indígenas, sino que en varias ocasiones afectan exclusivamente a contrayentes célticos (Beltrán 2001). Y, además, permite dar respuesta a uno de los rasgos más característicos de las tesserae celtibéricas, que no es otro que la aparición en la inmensa mayoría de estos textos de referencias a ciudades que permiten, con toda verosimilitud, identificar los documentos indígenas como pactos en los que una ciudad otorga a un individuo la ciudadanía local en una comunidad distinta de la suya.

Las tesserae celtibéricas desde el punto de vista material pueden ser de dos tipos, objetos de bulto redondo de forma figurada, generalmente zoomorfa (oso, cerdo, toro, pez, caballo, pájaro...), o en forma de manos estrechadas y láminas de bordes sinuosos o zoomorfas (Simón 2013).

Entre ellas dominan las de formulario unilateral que registran solo el nombre de la ciudad, generalmente el gentilicio acompañado de los términos kar o kortika, de los que el primero suele interpretarse como la referencia al acuerdo - $\mathrm{o}$ a la tessera - y el segundo a su carácter oficial, como en los casos de [SP.02.02] y [CU.01.01]: libiaka y libiaka kortika kar, relativos a Libia. Otras remiten a ciudades conocidas como Segobriga (sekobiriza [SP.02.43]), Virouia (uirouiaka [P.03.01]), Turiaso (TVRIASICA [P.01.01]), Arcobriga (ARCOBRIG[---] [Z.04.03]) o (Vxama) Argaela (AR[G]AILICA [P.02.02], o sin identificar: uetitanaka [Z.04.02], oilaunika [SP.02.27]. 

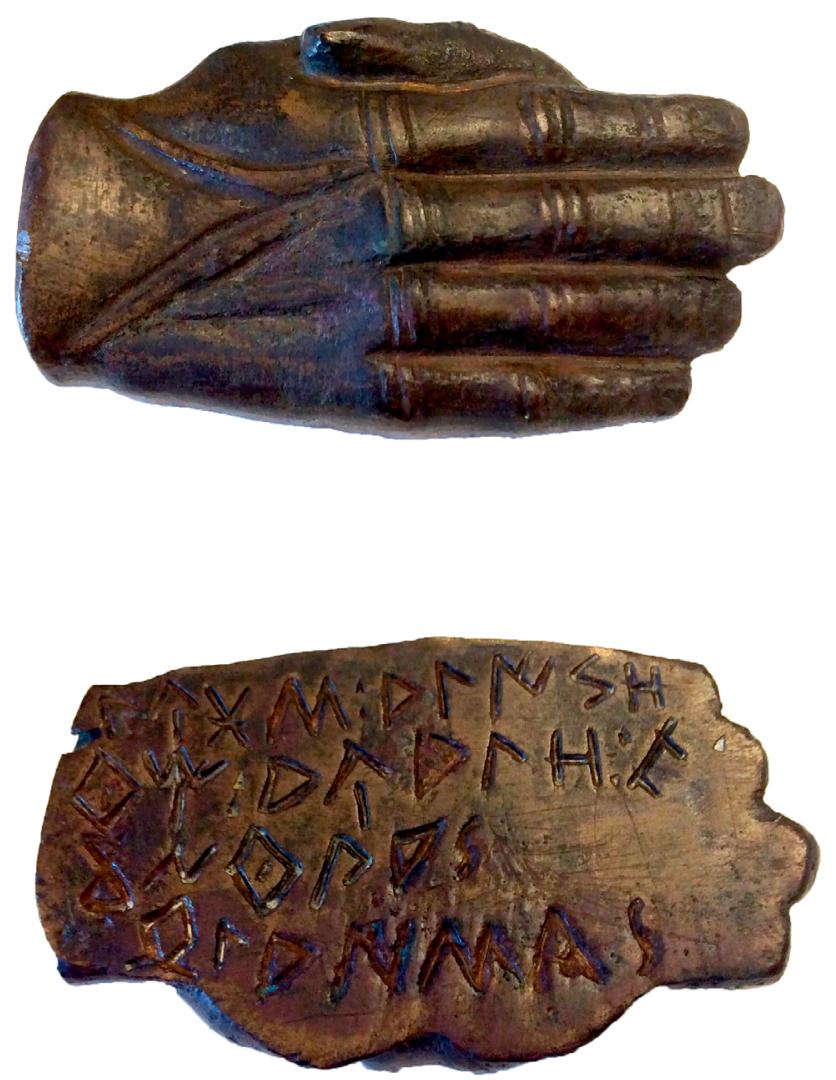

Fig. 6. Tésera Froehner [Z.00.01].

Lectura: lubos · alizo/kum • aualo · ke / kontebiaz / belaiskaz (fotos: M. Ruiz).

Pero también hay varios ejemplos de formularios bilaterales como las tesserae de la colección Froehner [Z.00.01], que recoge el pacto entre Contrebia Belaisca y lubos alizokum aualo ke(ntis), o de La Caridad [TE.04.11], entre Termes y lazuros kosokum.

Cabe señalar otro grupo que presenta textos menos transparentes, en los que la referencia a la ciudad no es siempre evidente, así como un pequeño grupo que alude exclusivamente a individuos como retukenos uisalikum [SP.02.05] o a una familia como atulnkum (quizá por atulikum [CU.00.01]). 
Más allá de la interpretación general, las tesserae hospitales celtibéricas plantean no pocos problemas de comprensión, agudizados por la proliferación en las últimas décadas de ejemplares falsificados que arrojan una sombra de duda sobre una parte importante del corpus.

De cualquier forma, estas inscripciones ponen de relieve la adopción de un tipo epigráfico de origen romano, de cuyas dos variedades, esto es los pactos de hospitium entre individuos y los pactos entre una ciudad y un individuo que comportan la concesión de la ciudadanía local, los celtíberos, significativamente, seleccionaron preferentemente la segunda. Este hecho pone de relieve no solo la importancia que entre estas comunidades entrañaba la condición cívica, sino sobre todo la capacidad para establecer vínculos cívicos entre comunidades diferentes, en ocasiones pertenecientes a etnias distintas, favorecidos sin duda por la comunidad lingüística y cultural (Beltrán 2010a; Beltrán et al. 2020).
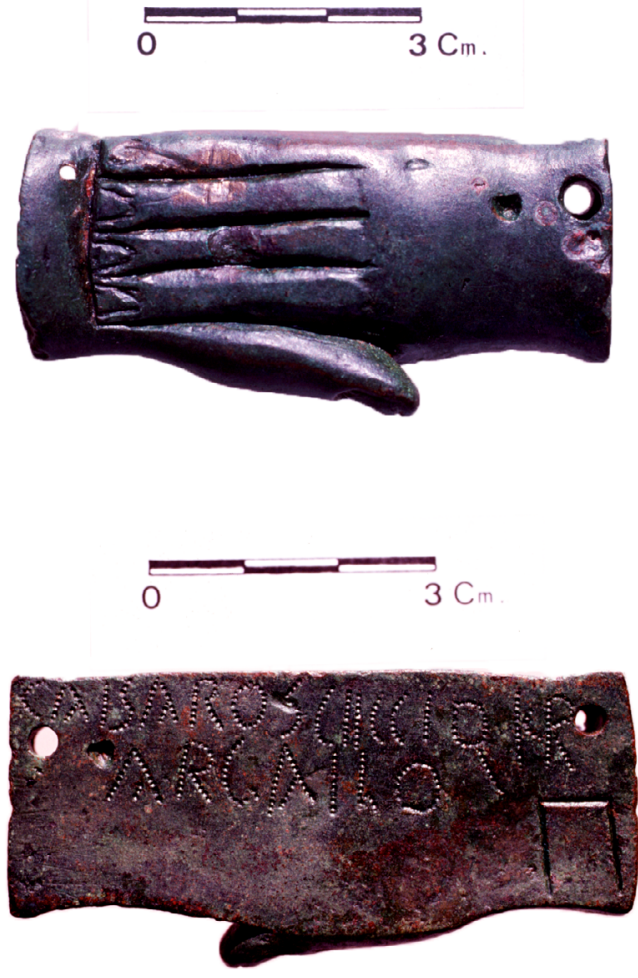

Fig. 7. Tésera de Paredes de Nava [P.02.01]. Lectura: CAISAROS CECCIQ(VM) K(A)R / ARGAILO (fotos: F. Beltrán). 


\section{f) Carta sobre lámina de plomo}

De este género de textos, característicos del ámbito ibérico y que a semejanza de sus modelos griegos contienen cartas, contratos o documentos de carácter comercial o económico, solo se conoce un ejemplar en lengua celtibérica procedente de La Manchuela, en la provincia de Cuenca, área limítrofe con el territorio culturalmente ibérico [CU.00.02]. Las características formales y el texto de este documento, que se plegaría para su envío una vez escrito, confirman su interpretación como carta de carácter comercial pues muestra en uno de los cuadrantes que quedaría al exterior el nombre del destinatario, expresado en la forma abulei kaikokum tatuz, interpretable como 'dése a Abulo de los Caicocos', y contiene la palabra silabur para la que se ha sugerido convincentemente el significado de 'plata'.

Se trata de un texto privado y propio de la escritura común, conservado gracias a haber sido grabado sobre plomo. Con seguridad existirían otros documentos similares sobre soportes perecederos, incluidas las tablillas enceradas pues se conoce al menos un estilo, todavía inédito, con inscripción celtibérica.

\section{g) Inscripciones sobre instrumentum}

Las inscripciones sobre instrumentum, en particular sobre vasijas u objetos de cerámica, constituyen la inmensa mayoría del corpus celtibérico. $\mathrm{Si}$ se toman en consideración también los rótulos compuestos por un solo signo el número se situaría en unos cuatro centenares, si bien en ocasiones resulta difícil discriminar si se trata realmente de un signo grafemático, correspondiente a una abreviatura, o de un mero signo geométrico coincidente con la forma de una letra.

La mayor parte de los rótulos están esgrafiados y realizados post cocturam, y pueden identificarse como marcas de propiedad. Entre ellos cabe destacar el conjunto de Numancia que presenta textos de varios signos con la particularidad de que los nombres consignados están formados con el sufijo -ko y podrían remitir a nombres familiares (nouantikum [SO.01.03], elatunako [SO.01.04], mautiko[---] [SO.01.08]), hecho que se repite en un grafito de La Caridad de Caminreal (kambarokum [TE.04.02]) y que podría identificar estos vasos como de uso familiar y ser significativo de su empleo en banquetes o ceremonias colectivos. En otros casos la interpretación del texto resulta más conflictiva como en la oinochoe de La Caridad en scriptura continua beskuau- 
zuetikubos [TE.04.01], en el que se ha querido ver una ofrenda o dedicatoria, si es que es esa realmente la lectura.

La mayor parte de los grafitos sobre cerámica, sin embargo, están compuestos de un solo signo y en ocasiones resulta difícil discriminar si se trata de letras o de signos geométricos, aunque en ambos casos su función parece ser la de marcas de propiedad cuando el contexto arqueológico es bien conocido. Este es el caso, por ejemplo, de las casas previas a 154 a. E. excavadas en la ciudad de Segeda (Burillo 2003). En esta fecha temprana, las cerámicas marcadas exhiben mayoritariamente trazos geométricos que no coinciden con ningún signo o que sí lo hacen como el correspondiente a ta —un aspa-, a $\mathbf{u}$ - una flecha orientada hacia arriba - o a ko — dos triángulos invertidos superpuestos-. Sean letras o meros signos, lo que resulta significativo es su concentración en ciertos espacios domésticos que refuerza su interpretación como marcas distintivas.

Diferente función desempeñarían las mucho más escasas letras grabadas ante cocturam que parecen corresponder a marcas de artesano como en el caso del rótulo ebura[z] sobre dos dolia de Contrebia Belaisca [Z.09.22] y mucho más evidentemente en el del rótulo estampillado, también sobre dolium, memo bel de Azuara (Zaragoza) [Z.14.01].

Entre los rótulos esgrafiados merecen una mención especial tres realizados sobre fusayolas, dos post cocturam y uno ante cocturam. Este último, procedente de Pintia (Peñafiel, Valladolid), parece contener más que un texto propiamente dicho, lo que se ha dado en denominar pseudo-escritura, es decir signos geométricos que imitan la escritura. Evidentemente los trazos fueron realizados por el artesano que confeccionó la pieza [VA.02.01]. A cambio, los otros dos realizados tras la cochura de la pieza, hay que atribuirlos al usuario: uno procede de Monreal de Ariza y podría contener un texto relativo a la función de la pieza — mejor que una alusión erótica - [Z.04.01], mientras que la otra, de texto aresinu, corresponde probablemente un nombre personal [Z.07.01]; esta última pieza procede de Segeda y se data en la primera mitad del siglo II. Lo que resulta relevante, máxime dada la elevada cronología de algunas piezas, es el hecho de que, siendo la actividad textil una tarea básicamente femenina, estos objetos destinados al hilado ponen de manifiesto una familiaridad con la escritura de las mujeres que es un sector de la sociedad al que tradicionalmente se le atribuye un escaso contacto con ella. Debe subrayarse también que esta práctica, casi desconocida en el mundo romano, está también atestiguada en el ibérico, si cabe aún más reforzada por la presencia 
de alfabetos o sinarios sobre algunas fusayolas (Ferrer 2014; Beltrán, Jordán y Simón e. p.). También algunas pesas de telar muestran marcas [Z.09.23] (Beltrán, Jordán y Simón e. p.).

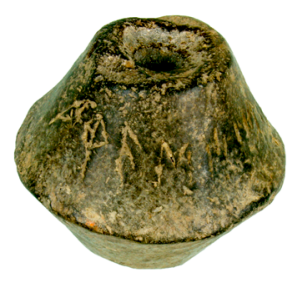

Fig. 8. Fusayola procedente de Segeda I [Z.07.01]

Lectura: aresinu (foto: Proyecto Segeda).

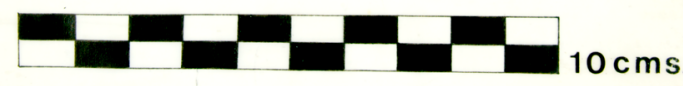

Existen también otras categorías de inscripciones sobre instrumentum menos habituales como las pintadas sobre vasos cerámicos, caso de un vaso de Numantia [SO.01.02] o un dolium [LO.04.01], las realizadas sobre dos trullae de plata de Termes [SO.05.01 y 02] o marcas sobre un proyectil de catapulta de piedra procedente de Contrebia Belaisca [Z.09.25] así como sobre los fustes de columna del porticado existente en el centro monumental de esta ciudad, algunas correspondientes al signario ibérico.

\subsection{Sistemas de escritura.}

Los celtíberos utilizaron dos sistemas de escritura para escribir su lengua: el signario paleohispánico y el alfabeto latino.

\subsubsection{El signario paleohispánico}

La mayoría de las inscripciones celtibéricas están escritas en signario paleohispánico. Este sistema gráfico es fruto de la adopción y adaptación del signario ibérico levantino o del nordeste. Es un semisilabario, es decir, se utilizan dos tipos de signos: los fonemogramas para vocales, sonantes y posibles fricativas o africadas y los silabogramas para secuencias silábicas de estructura [oclusiva + vocal], ba, pa, da, ta, ga, ka, etc.

En la adopción heredaron las "inconveniencias" de cualquier semisilabario: ¿cómo indicar que una palabra termina en una determinada oclusiva?, ¿cómo escribir una secuencia de oclusiva + oclusiva, -kt-, o de oclusiva + 
silbante, -ks? Se pensó que también habían recogido, en principio, las propias del ibérico, como la no diferenciación entre oclusivas sonoras y sordas.

Dicha adopción supuso, como era de esperar, una adaptación y esta se produjo en un triple aspecto: reducción, redistribución e innovaciones.

1. Reducción: redujeron el número de signos y los dejaron en 26.

1.1. Vibrantes: el celtibérico prescindió de uno de los signos para una de las vibrantes en ibérico y generalizó el otro.

1.2. Nasales: el signario levantino ibérico presentaba un signo para $/ \mathrm{m} /$, uno para $/ \mathrm{n} /$, y otro cuyo contenido fonológico es discutido, pero en el que parece obligatorio el rasgo de la nasalidad. El celtibérico parece que solo poseía dos nasales, la labial y la dental, y eligió dos de los tres signos recién indicados. La singularidad consiste en que no todo el celtibérico utilizó los mismos y se pueden observar dos variantes diatópicas en este caso:

- La variante oriental, cuyo centro epigráfico más importante es Botorrita (Zaragoza).

- La variante occidental, con centro en Luzaga (Guadalajara).

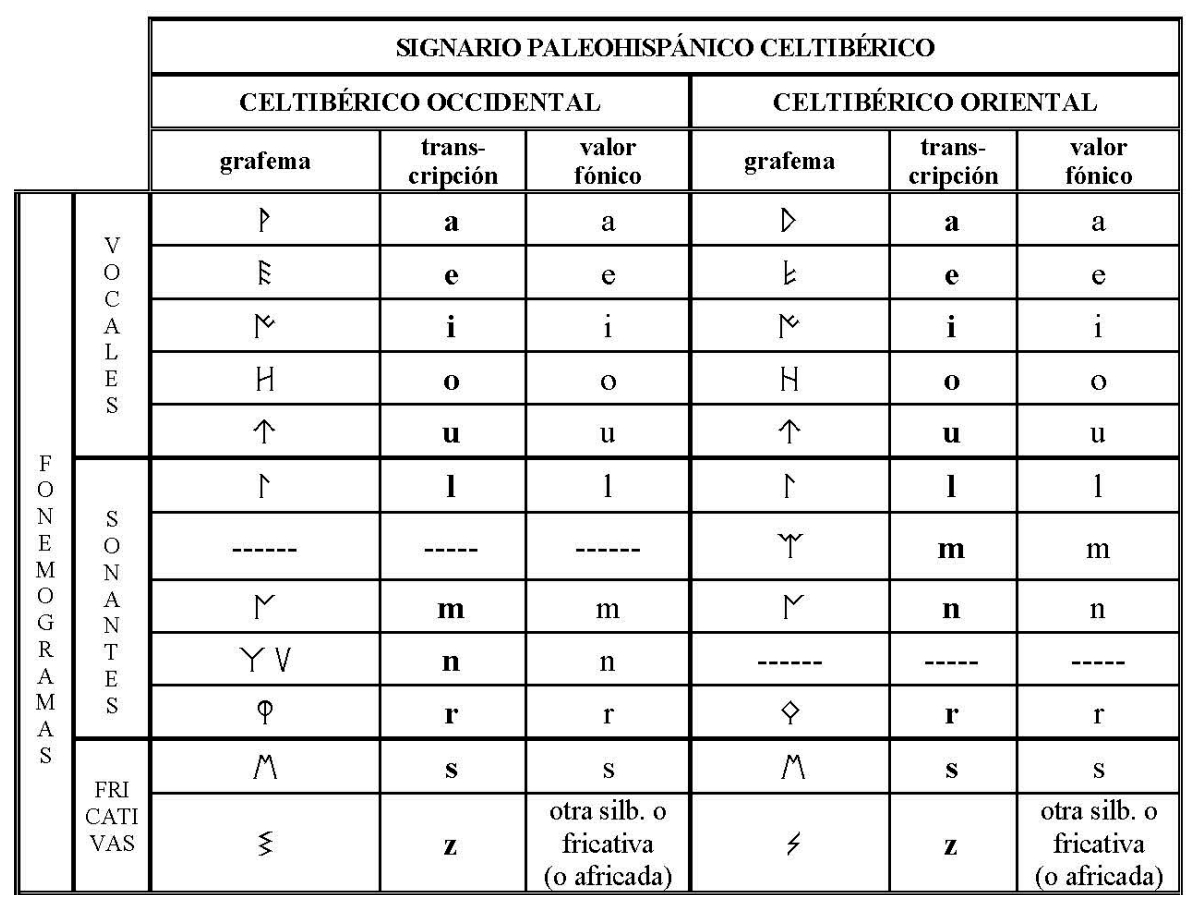




\begin{tabular}{|c|c|c|c|c|c|c|c|c|c|}
\hline & & & \multicolumn{6}{|c|}{ SIGNARIO PALEOHISPÁNICO CELTIBÉRICO (continuación) } \\
\hline & & \multicolumn{5}{|c|}{ CELTIBÉRICO OCCIDENTAL } & \multicolumn{3}{|c|}{ CELTIBÉRICO ORIENTAL } \\
\hline & & \multicolumn{2}{|c|}{ grafema } & \multicolumn{2}{|c|}{$\begin{array}{c}\text { trans- } \\
\text { cripción }\end{array}$} & $\begin{array}{c}\text { valor } \\
\text { fónico } \\
\end{array}$ & grafema & $\begin{array}{c}\text { trans- } \\
\text { cripción }\end{array}$ & $\begin{array}{c}\text { valor } \\
\text { fónico }\end{array}$ \\
\hline & \multirow{5}{*}{$\begin{array}{c}\text { OR } \\
\text { DEN } \\
\text { LA } \\
\text { BIAL }\end{array}$} & \multicolumn{2}{|c|}{ l } & \multicolumn{2}{|c|}{ ba } & $\mathrm{ba} / \mathrm{pa}$ & I & ba & $\mathrm{ba} / \mathrm{pa}$ \\
\hline & & \multicolumn{2}{|c|}{ W } & \multicolumn{2}{|c|}{ be } & $\mathrm{be} / \mathrm{pe}$ & 8 & be & $\mathrm{be} / \mathrm{pe}$ \\
\hline & & \multicolumn{2}{|c|}{$\Gamma$} & \multicolumn{2}{|c|}{ bi } & $\mathrm{bi} / \mathrm{pi}$ & $\Gamma$ & bi & $\mathrm{bi} / \mathrm{pi}$ \\
\hline & & \multicolumn{2}{|c|}{ 米 } & \multicolumn{2}{|c|}{ bo } & bo/po & * & bo & $\mathrm{bo} / \mathrm{po}$ \\
\hline & & \multicolumn{2}{|c|}{ ( } & \multicolumn{2}{|c|}{ bu } & $\mathrm{bu} / \mathrm{pu}$ & $\square$ & bu & $\mathrm{bu} / \mathrm{pu}$ \\
\hline $\begin{array}{l}\mathrm{S} \\
\mathrm{I}\end{array}$ & \multirow{5}{*}{$\begin{array}{c}\text { OR } \\
\text { DEN } \\
\\
\text { DEN } \\
\text { TAL }\end{array}$} & $x$ & Ж & da & ta & $\mathrm{da} / \mathrm{ta}$ & $x$ & ta & $\mathrm{da} / \mathrm{ta}$ \\
\hline $\begin{array}{l}\mathrm{L} \\
\mathrm{A}\end{array}$ & & $\oslash \diamond$ & $\otimes \otimes$ & de & te & $\mathrm{de} / \mathrm{te}$ & $\vartheta$ & te & $\mathrm{de} / \mathrm{te}$ \\
\hline $\begin{array}{l}\mathrm{B} \\
\mathrm{O}\end{array}$ & & $\Psi(T)$ & $\Psi(\Psi)$ & di & ti & $\mathrm{di} / \mathrm{ti}$ & $\Psi$ & ti & $\mathrm{di} / \mathrm{ti}$ \\
\hline $\begin{array}{l}G \\
R\end{array}$ & & ப(山) & ш (سا) & do & to & $\mathrm{do} /$ to & 山 & to & $\mathrm{do} / \mathrm{to}$ \\
\hline $\begin{array}{l}\text { A } \\
\text { M }\end{array}$ & & $\Delta$ & $\Delta$ & du & tu & $\mathrm{du} / \mathrm{tu}$ & $\Delta$ & tu & $\mathrm{du} / \mathrm{tu}$ \\
\hline $\begin{array}{l}\text { A } \\
\text { S }\end{array}$ & \multirow{5}{*}{$\begin{array}{c}\text { OR } \\
\text { DEN } \\
\\
\text { VE } \\
\text { LAR }\end{array}$} & $\Lambda \wedge$ & A & ga & ka & $\mathrm{ga} / \mathrm{ka}$ & $\lambda$ & ka & $\mathrm{ga} / \mathrm{ka}$ \\
\hline & & $<c$ & $\leqslant \ll \in \mathbb{C}$ & ge & ke & $\mathrm{ge} / \mathrm{ke}$ & $\leqslant$ & ke & $\mathrm{ge} / \mathrm{ke}$ \\
\hline & & 51 & $\$ 1$ & gi & ki & $\mathrm{gi} / \mathrm{ki}$ & 5 & ki & gi/ki \\
\hline & & Z & $\mathbb{Z}$ & go & ko & go/ko & Z & ko & $\mathrm{go} / \mathrm{ko}$ \\
\hline & & $\diamond 0$ & $\diamond \odot$ & gu & ku & $\mathrm{gu} / \mathrm{ku}$ & $\odot$ & ku & $\mathrm{gu} / \mathrm{ku}$ \\
\hline
\end{tabular}

Tabla 3. El signario celtibérico y sus modalidades.

2. Redistribución: En concreto nos estamos refiriendo al uso en celtibérico de los grafemas que en ibérico indicaban una fricativa silbante, con seguridad, y otro elemento fónico cuya realización podría ser una fricativa (otra silbante) o una africada.

La escritura ibérica presenta los signos san y sigma, que se han transcrito tradicionalmente como $<\dot{s}>\mathrm{y}<\mathrm{s}\rangle$, correspondientemente. Todavía no sabemos muy bien qué distinción estaban marcando en ibérico. Los celtíberos siguieron manteniendo ambos signos.

Aunque en un principio se pensó que sigma estaba indicando desde el punto de vista fonético algo parecido a una fricativa dental sonora [ð] o sorda $[\theta]$, desde mediados del siglo XX se impuso la idea de Tovar de que nos encontrábamos ante un caso de arbitrariedad gráfica a la hora de indicar la única silbante celtibérica, heredera de la indoeuropea. Ha habido que esperar hasta los años noventa, para que después de un par de detenidos estudios, Villar haya logrado demostrar que dicha arbitrariedad no existe (Villar 1993; 1995; 
1996). Otra cuestión es determinar qué es lo que grafiaba la sigma, pues parece haber consenso en que san indicaba una silbante sorda (posiblemente apical).

3. Innovaciones:

3.1. Resolución del grupo muta cum liquida: No está muy claro cómo se comportaba en este aspecto el ibérico, pues no tenemos datos seguros de que tales grupos existiesen en esta lengua. Por lo que respecta al celtibérico la solución puede ser triple. Primero, mediante la utilización del silabograma con la vocal que iba tras la líquida, tipo kolounioku. Está por confirmar que se utilizase un silabograma con otra vocal. Segundo, con metátesis gráfica aprovechando la vocal del silabograma, tipo konterbia. Y tercero, ignorando la líquida, tipo kontebakom por ${ }^{\star}$ konterebakom o ${ }^{\star}$ konterbakom.

3.2. Escritura redundante: en el corpus epigráfico celtibérico se han detectado varios casos en los que tras un silabograma aparece de manera sistemática el fonemograma de la vocal correspondiente, tipo tu-u. Así, de momento, en un grafito de Numancia [SO.01.02], luanikoo - koorinau; en cuatro estelas de Peñalba de Castro, antigua Clunia (BU): [BU.06.01] kaabaarinos, [BU.06.02] mukuukaaiau, [BU.06.04] [---]ikooguustuunuo, [BU.06.05] muguuroskiimine+; y en una tésera de Sasamón (BU) [BU.01.01]: A: guirorekiios monituukoos - nemaios B: aletuures. Hay también algún caso de escritura no sistemática, como en [NA.07.02] tertabiizum • kaạr, que todavía está por explicar.

Parece que este uso es de fecha muy avanzada y se debe a la influencia del alfabeto latino. Se estaría empezando a perder la conciencia del carácter semisilábico del signario y, de alguna manera, se estaría alfabetizando.

3.3. Sistema dual de escritura: como ya se ha indicado, en un principio se pensaba que el signario paleohispánico en general y el ibérico levantino en particular no reflejaba la diferencia entre sílaba compuesta por una oclusiva sorda y sonora. Maluquer 1968 empezó a detectar en ciertas piezas ibéricas esta posibilidad, aunque de manera restringida. El mecanismo era el siguiente: la sílaba con oclusiva sonora se indicaba mediante un silabograma simple, mientras que la sílaba con oclusiva sorda lo hacía mediante un silabograma complejo, es decir, el simple con la adición de un trazo. Fue Ferrer 2005 quien demostró que en realidad este fue el funcionamiento general y regular del ibérico levantino entre al menos los siglos V y III-II a. E. Se le ha denominado sistema dual de escritura. El mismo autor también avanzaba en el trabajo indicado la posibilidad de uso de este sistema en celtibérico, pero fue Jordán 
2005 el que dio pruebas de peso sobre su uso entre los celtíberos y presentó las piezas en las que consideraba que se utilizaba: la leyenda monetal leída de manera habitual bormeskom / bormesko [MON.81], que quedaba entonces como tarmeskom / tarmesko; la tésera de Úxama [SO.06.02]; la tésera de $\underline{k a-}$ teiko [SP.02.19]; el bronce de Cortono (al que habría que denominar Gortono, en todo caso) [SP.02.03]; y el bronce de Luzaga [GU.01.01]. Los cinco documentos presentaban escritura occidental. Ha sido tras la aparición de la fálera de Armuña de Tajuña, cuando Jordán ha planteado el uso del sistema dual en otras piezas no sólo de la variante occidental, sino también de la variante oriental, como es la misma fálera indicada (sobre esta cuestión, vid. Velaza e. p.; Jordán 2017; Ferrer 2017).

\subsubsection{El alfabeto latino}

Si los celtíberos adoptaron y adaptaron el signario paleohispánico levantino de los iberos, hicieron lo mismo con los latinos y su alfabeto. Es este un episodio más del proceso de latinización que se dio en Hispania y que también sufrieron los iberos, aunque estos apenas dejaron testimonio de su lengua escrita en alfabeto latino (Simón 2014; 2019). Los celtíberos nos legaron un corpus un poco más nutrido. El caso extremo es el de la lengua lusitana, lengua paleohispánica que solo escribió en alfabeto latino. ${ }^{17}$

Las piezas que están escritas en este sistema de escritura y lengua celtibérica recogidas aquí son: [MON.89] leyenda SEGOBRIS; [MON.67] leyenda CLOVNIOQ(VM); [SO.05.01] trulla de Tiermes; [SO.05.02] trulla de Tiermes; [IR3] grafito de Numancia; [S.01.01] Estela de Iuliobriga; [T1.1.1] tésera AVILACA; [P.01.01] tésera TVRIASICA - / CAR; [CC.04.01] tésera TAMVSIENSI / CAR; [P.02.02] tésera AR[G]AILICA CAR; [P.02.01] tésera CAISAROS CECCIQ(VM); [SP.02.22] tésera DVREITA; [Z.04.03] tésera ARCOBRIG(---); [SE.03.01] tésera CAAR; [BU.02.01] tésera AMBATO VIROVARCO; [BU.01.02] tésera TRIDONIECV; [SP.02.26] tésera +ILICICOS; [LO.04.03]

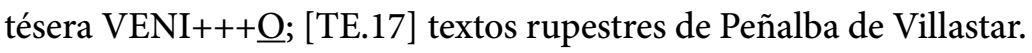

A esta lista habría que añadir el Bronce de Novallas, que ha demostrado que los celtíberos también llevaron a cabo un proceso de adaptación del alfabeto latino a su lengua. En concreto, junto a la $S$ propia del alfabeto latino, aparece en este documento una $S$ con un trazo horizontal en su base a modo de subrayado que sobresale por su derecha. Lo curioso de este nuevo signo es

17 Sobre las adaptaciones del alfabeto latino para escribir lenguas paleoeuropeas puede verse la contribución de I. Simón en el presente volumen. 
que ya había sido detectado en [TE.17.03] y [TE.17.21], la gran inscripción de Peñalba y una menor del mismo sitio, pero se pensó que no era pertinente el trazo en cuestión. Con el Bronce de Novallas y su comportamiento en él está claro que sí lo era (Beltrán et al. 2013).

Si en párrafos anteriores hemos hablado de la influencia del alfabeto latino en el uso del signario paleohispánico a propósito de la redundancia vocálica, también parece posible hacerlo a la inversa. Esto es, de la influencia del signario paleohispánico celtibérico sobre el alfabeto latino. Simón apunta de manera muy convincente el uso de la letra $\mathrm{Q}$ en un importante grupo de nombres de familia o genónimos en epigrafía latina y ambiente indígena que aparecen en genitivo del plural (Simón 2012). La mayoría aparecen de forma abreviada -Q frente a una minoría que presenta la terminación-QVM. Se estaría operando una interferencia grafemática entre el silabograma ku y la letra $Q$.

\subsection{Fórmula onomástica personal}

La designación de las personas en celtibérico se realizaba mediante un nombre personal (NP) que, en ciertos contextos, puede aparecer solo - por ejemplo en ciertos grafitos-, pero que habitualmente va seguido de un nombre familiar (NF), rasgo este peculiar de la fórmula onomástica personal celtibérica que en el Mediterráneo antiguo solo comparte con los romanos, etruscos y otros pueblos de la península Itálica. El NF suele derivar de un NP mediante el sufijo - $k o$, precedido por una vocal $(i, o, a)$ y, generalmente, se expresa en genitivo de plural con la desinencia -um. Así, por ejemplo, tirtanikum, derivado de tirtanos. En las variantes más completas y formales estos dos elementos pueden ir acompañados del nombre del padre $(\mathrm{P})$ en genitivo singular, solo u ocasionalmente, seguido de la palabra kentis, 'hijo', que en ocasiones se abrevia. Este proceder parece fruto de la influencia romana en cuya fórmula onomástica es habitual la abreviatura de los términos filius / filia - y de otras muchas palabras como el praenomen - frente la epigrafía celtibérica -o ibérica- en la que las abreviaturas son excepcionales. Más difícil es establecer si también es fruto de la influencia romana la incorporación a la fórmula onomástica personal celtibérica del nombre del padre, poco habitual y último elemento en ser incorporado, según se deduce de su posición final.

No existen diferencias entre la fórmula masculina y la femenina, aparte de un diferente repertorio de NNPP. 
Francisco Beltrán Lloris | Carlos Jordán Cólera

a) Fórmula onomástica masculina:

$\begin{array}{lll}\mathrm{NP} & \mathrm{NF} & \mathrm{P}\end{array}$

CALAITOS

[TE.17.05]

retukenos uisalikum

[SP.02.05]

lubos kounesikum

melmunos [Z.09.01]

lubos

alizokum

aualo ke(ntis) [Z.00.01]

b) Fórmula onomástica femenina:

NP

NF

$\mathrm{P}$

munika

[Z.09.03, I.6]

sura

matulokum

[Z.09.03, I.9]

koitina

abokum

useizunos

$[$ Z.09.03, II.15]

El mayor repertorio de fórmulas onomásticas lo ofrece el tercer bronce de Botorrita [K.09.03], en el que entre los nombres personales más frecuentes se encuentran akuia, arkanta o munika (femeninos) y bursu, koitu, likinos, mezukenos, retukenos o terkinos (masculinos). Entre los nombres familiares destacan abokum, ensikum, loukanikum, turumokum y uiriaskum (Beltrán, De Hoz y Untermann 1996).

Hasta el momento solo en un caso, la losa de Ibiza, está comprobada la adición a NP, NF y P de la ciudad de origen, la origo de los romanos:

$\begin{array}{lllll}\text { NP } & \text { NF } & \mathrm{P} & \mathrm{O} & \\ \text { tirtanos } & \text { abulokum } & \text { letontunos } & \underline{\text { belikios }} & \text { [IB.01.01] } \\ & & \underline{\text { ke(ntis) }} & & \end{array}$




\section{Debates en el estudio de la lengua y la cultura epigráfica celtibé- ricas. Retos de futuro}

\subsection{Problemas lingüísticos}

\subsubsection{El lugar del celtibérico dentro de la familia celta}

De manera general se ha considerado que el celtibérico es un dialecto celta arcaico porque se separaría muy pronto de la lengua celta originaria, el proto-celta. Es este un punto en el que vienen a coincidir la mayoría de los autores que se han ocupado de estudiar el proceso de dialectalización de las lenguas celtas, ya sea en su versión galo-britónica; ${ }^{18}$ ya en la versión del celta insular. ${ }^{19}$ Ahora bien, en honor a la verdad, como indica Sims-Williams establecer este proceso depende directamente del conocimiento que se tenga de la (pre)historia de los movimientos de las poblaciones hablantes de esas lenguas y este todavía no está bien determinado (Sims-Williams 2007). En este sentido, Schrijver presenta una interesante variante areal del árbol genealógico celta que obligan a replantearse la localización de la "patria originaria" de los celtas hacia el norte de la península ibérica, el Sur de Francia o el norte de Italia (pero al sur de los Alpes, no al norte) y abren la posibilidad de contactos dialectales de esas lenguas celtas con otras del mundo circundante (Schrijver 2015). El celtibérico, por ejemplo, habría estado en contacto con el ibérico y el vasco. ${ }^{20}$

\subsubsection{Posibles variantes cronológicas y dialectos celtibéricos}

La existencia de distintas fases cronológicas (unidades sincrónicas) en el corpus celtibérico es defendida por De Bernardo. ${ }^{21}$ Establece un celtibérico arcaico frente a uno clásico. El rasgo más definitorio del celtibérico arcaico que ha hallado la autora es el tratamiento de ${ }^{\star}-\bar{o}$. Sin embargo, la evolución que propone no es definitiva y los datos que aporta pueden explicarse de otra manera o se basan en lecturas problemáticas.

En la definición que se ha dado al principio del celtibérico ( $\$ 1.2)$, se ha dicho que se considera que los berones, además de los carpetanos, hablaban

18 Koch 1992; Schmidt 1977b; 1980; 1986; 1988a; 1988b; 2001, 598; o la variante de De Bernardo 2002; 2006; 2007a; 2007b; 2013, por ejemplo.

19 Cowgill 1975; McCone 1996; 2001; Schrijver 1995.

20 Para la relación entre lengua y cultura material, así como el proceso de celtización, $\$ 1.3$

21 P. ej., De Bernardo 2011. 
esa lengua. De hecho, se ha llegado a plantear que los primeros podrían usar una variante dialectal propia. ${ }^{22}$ Sin embargo, la información, procedente del material numismático y seis téseras, es más bien escasa y tampoco la documentación indirecta en la que se recoge el propio etnónimo de los Berones, topónimos, antropónimos y teónimos, posibilita aislar una serie de características lingüísticas propias que permita hablar de un dialecto berón.

Prósper propone, por su parte, un par de variantes dialectales, una oriental y otra noroccidental arévaca, que se caracterizarían por la evolución de la secuencia $-V(C) t y V->-V(C) t s V$ - y evolución ${ }^{*}$-ekt- > * ext- > eyt- (o, menos probable, $-\bar{e})$, correspondientemente (Prósper 2005; 2015). Aceptarlas sin más es problemático, ya que las etimologías que propone la autora no están confirmadas. Además, el corpus celtibérico es todavía demasiado magro, tiene mucho material portátil y la mayoría no está ni bien localizado geográficamente ni bien contextualizado arqueológicamente. En definitiva, habrá que esperar más datos para confirmar o negar la realidad de esas variantes dialectales del celtibérico.

\subsubsection{Grado de desciframiento del celtibérico}

El celtibérico es una lengua de corpus fragmentariamente atestiguada. ${ }^{23} \mathrm{La}$ cantidad de documentación es pequeña. En total, rondará las mil cien palabras. La mayoría, lamentablemente, pertenece a un campo léxico determinado, la onomástica, por lo que muchas de ellas están repetidas o simplemente son variaciones de una misma palabra. La naturaleza de los textos favorece la aparición de nombres personales y de ciudades que constituyen el contenido habitual de las leyendas monetales, los grafitos sobre instrumentum domesticum, las inscripciones funerarias y las tesserae hospitales, donde es lógico que aparezca el nombre de la comunidad cívica emisora, del poseedor o del fabricante, del finado o de los contrayentes del pacto. Ni siquiera los textos más largos como los bronces de Botorrita (BB) se libran de esta preferencia por la onomástica, pues el primer bronce (BBI), algún tipo de ordenación jurídica, presenta, por una de sus caras, un listado de fórmulas onomásticas y el tercero (BBIII) es un listado de nombres con alrededor de 195 fórmulas onomásticas.

Esta fragmentariedad a la que aludimos provoca que el conocimiento lingüístico del celtibérico también sea fragmentario y que, en definitiva, toda-

22 Labeaga y Untermann 1993; vid. también García-Bellido 1999; Villar 1995b, 343-344.

23 Una de las Trümmersprache, según Untermann 1980. 
vía no se haya podido descifrar completamente esta lengua. Podemos afirmar que la imposibilidad de una traducción "lingüística" fidedigna e inamovible es aplicable al 90\% o más del léxico de la su documentación. kentis [gentis] 'hijo', -kue 'y', nekue 'y no', -ue 'o', son las únicas palabras sobre las que existe un acuerdo unánime sobre su significado. El resto está todavía por confirmar $(\$ 1.4 .3)$.

\subsubsection{Puntos conflictivos en el plano fónico}

Muchos son los problemas que quedan por resolver en este plano. El que más atención ha recibido por parte de la paleohispanística moderna es el referido a las fricativas y africadas en celtibérico. Así, para empezar, hay una clara distinción a la hora de considerar el tratamiento de ${ }^{*} s$ originaria intervocálica en esta lengua. Se reconocen dos escuelas o tradiciones:

1.- F. Villar 1993; 1995; 1996, propuso que sufría un proceso de sonorización, según el cual, *vocal-s-vocal $>$ vocal- $z$-vocal. Por ejemplo: alizos [CSB.00.01], alizokum [Z.00.01] < *aliso- 'alisio'. Su grafía en el signario paleohispánico era sigma, que transcribió z. Sería un alófono silbante sonoro, que, posteriormente, debido a la evolución de las oclusivas dentales, pudo acabar siendo un fonema $/ \mathrm{z} / \mathrm{o} / \mathrm{\partial} /$.

2.- J. Untermann, sin embargo, consideró que la silbante originaria en posición intervocálica se mantenía en celtibérico. ${ }^{24} \mathrm{Su}$ expresión gráfica era, entonces, san. Aquellos casos (en todas las posiciones excepto en inicial de palabra o de segundo miembro de compuesto) en que aparece el signo sigma intervocálico se debe a la evolución de una dental sonora celta, procedente bien de dental sonora o dental sonoro aspirada indoeuropea. Se entiende perfectamente la transcripción del profesor alemán como $ð$, ya que su contenido fónico sería el de una fricativa interdental sonora.

Por lo demás, hay cierto acuerdo en aceptar que la silbante originaria se mantenía en el resto de posiciones.

En estrecha relación con este asunto, se encuentra la evolución de las oclusivas dentales y velares. En celtibérico hay datos que apuntan a que los componentes sonoros del orden dental, con seguridad, y velar, con dudas, estaban sufriendo un proceso de relajación articulatoria o lenición, que se refleja en diferentes grados y que dio lugar a diferentes resultados, como, por ejemplo, fricativa interdental $ð$ (en posición intervocálica y entre sonante y 
vocal); en posición final absoluta, en cambio, se neutralizó con ${ }^{\star}-t$ en ${ }^{\star}-\theta$, fricativa interdental sorda. En este complicado panorama, hay que contar, además, con el encuentro de esa silbante y esas dentales con otras consonantes (tipo -ps-, -ks-, -kt-, -nt-, -nd-, -tyo-, etc.) cuyo comportamiento se está discutiendo actualmente. ${ }^{25}$ Con este panorama queda por definir la unidad o unidades fonológicas correspondientes.

\subsubsection{Puntos conflictivos en el plano morfológico}

Como ya se ha indicado, la morfología nominal celtibérica presenta dos rasgos característicos. Por un lado, el genitivo del singular de los temas en -o, que termina precisamente en - $o$. Su explicación sigue abierta. Todos los autores que se han ocupado de la cuestión apuntan a algún tipo de influencia del patrón pronominal, aunque no está claro cómo. ${ }^{26} \mathrm{Se}$ aparta de esta explicación Schmidt para el que la terminación procede del ablativo ${ }^{*}-\bar{o} d$, al modo eslavo y báltico oriental. Sigue esta idea De Bernardo en diferentes trabajos, ${ }^{27}$ pero el tratamiento de la vocal hace difícil asumir esta propuesta.

La otra característica morfológica nominal es la existencia de ablativo en celtibérico, según ya se ha expuesto, a la que muchos autores se oponen. ${ }^{28} \mathrm{La}$ negativa a aceptar este caso en celtibérico se basa, en definitiva, en una visión muy determinada del sistema morfológico nominal indoeuropeo: sanscritista y sincretista. Además, se hace necesario recurrir a explicaciones morfo-fonológicas de una serie de terminaciones (-az, -uz, -iz, -ez en la epigrafía monetal; -z, -tuz en elementos verbales) y mediante leyes fonéticas y recursos gráficos difícilmente sostenibles.

\subsection{Problemas epigráficos}

Las principales características de la cultura epigráfica celtibérica han sido discutidas más arriba (especialmente en $₫ 1.5$ ). La relevancia que el contacto con otras culturas epigráficas, en particular con la ibérica y con la romana, tuvo en el desarrollo de la epigrafía celtibérica es incuestionable. Así, los dos sistemas de escritura que empleó sucesivamente se apartan muy levemente de sus modelos ibérico y latino, en los que introducen modificaciones mínimas.

25 Un estado de la cuestión en Jordán 2019, 115-134.

26 Untermann 1967; Hamp 1971; Schmidt 1976; 1977a; 1991; Prosdocimi 1991; Eska 1988; 1989, 160; 1995; Watkins 1999; Eska y Wallace 2001.

27 De Bernardo 1993; 2002, 97-98; 2003; 2007b, 161-169, etc.

28 Isaac 2002; De Bernardo 2011, por ejemplo. 
Con la cultura escrita ibérica la celtibérica comparte ciertos tipos de epitafio dotados de líneas de pautado que aparecen en zonas confinantes como Belchite [Z.17.01; Rodríguez y Diez 2018] —y el beligiense de Ibiza [IB.01.01]—, el uso de láminas de plomo para escribir cartas - aunque sea en un solo caso [CU.00.02] - y la rotulación de instrumentos textiles como las fusayolas (Beltrán, Jordán y Simón e. p.). Con la romana, aunque esta conexión haya sido cuestionada, ${ }^{29}$ lo demuestra el empleo de las téseras de hospitalidad y en general el uso del bronce como soporte, particularmente en placas de formato grande y medio como las de Botorrita o Novallas que remiten directamente a modelos romanos, sin que ello obste para dar lugar a desarrollos particulares como lo demuestra el hecho de que un hábito excepcional en Italia como el de las téseras de hospitalidad de bronce tuviera en la Celtiberia un empleo tan intenso en términos comparativos (Beltrán 2018).

La debilidad de la epigrafía pública y monumental que denuncia el escasísimo número de epitafios celtibéricos es un hecho vinculado sin duda al limitado desarrollo monumental de las ciudades celtibéricas, entre otros factores, entre los que se cuenta un alfabetismo restringido y, en consecuencia, la falta de interés por canalizar a través de este conducto la afirmación social individual que parece ser el motor de la producción epigráfica coetáneamente en las ciudades del litoral mediterráneo. En este sentido puede entenderse desde la misma perspectiva que una buena parte de la producción epigráfica celtibérica emane de las autoridades cívicas: leyendas monetales, téseras de hospitalidad y placas de bronce. La inmensa mayor parte de las inscripciones celtibéricas son de carácter privado, es decir están concebidas para ser leídas por muy pocos destinatarios: marcas y rótulos sobre cerámica y otros objetos, téseras de hospitalidad, epígrafes sobre láminas de bronce, la carta sobre lámina de plomo e incluso los grafitos rupestres de Peñalba [TE.17], en su mayoría de pequeño tamaño, en ubicaciones poco visibles y de escasa profundidad.

Resulta extremadamente difícil fijar la cronología de las inscripciones celtibéricas dentro de la relativamente limitada horquilla temporal en la que se sitúan, entre fines del siglo III a. E. y un momento indeterminado del I d. E., si bien en su mayoría datan del periodo entre mediados del II a. E. y fines del I a. E.: el único ejemplo, aislado, por ahora de datación anterior es la fálera de Armuña de Tajuña, fechada en los últimos años del siglo III a. E. por criterios numismáticos. Las posibilidades de datación de las inscripciones celtibéricas

29 La dependencia de modelos romanos de algunos tipos, evidente en nuestra opinión (Beltrán 2018), ha sido cuestionada (Prag 2013). 
dependen en gran medida de su recuperación en un contexto arqueológico. Es cierto que los materiales numismáticos en particular cuentan con algunos elementos adicionales de seriación que permiten más bien una datación relativa que absoluta, dentro del periodo de producción monetal que, con muchas dudas, se sitúa entre mediados del siglo II y del siglo I a. E. A cambio las téseras de hospitalidad carecen de contexto arqueológico habitualmente hasta el punto de que solo una, procedente de La Caridad de Caminreal, puede datarse aproximadamente dentro de la horquilla que marca la estratigrafía general del yacimiento entre fines del siglo II y 70 a. E. Una cronología similar, con el mismo horizonte final, ofrecen los bronces de Botorrita, en particular el primero que es el único recuperado en excavación y que cuentan con un paralelo local latino, la tabula Contrebiensis, datado por criterios internos en 87 a. E. Diferentes indicios, entre los que debe consignarse el empleo del alfabeto latino o la notación redundante de las vocales en la escritura semisilábica, inducen a atribuir una fecha avanzada, posiblemente augústea, al conjunto de grafitos rupestres de Peñalba de Villastar [TE.17] que parecen responder a un periodo de frecuentación más bien breve o al bronce de Novallas. Normalmente, los grafitos sobre cerámica tienen una mejor datación; los más antiguos, hallados en Segeda, parecen remontarse a mediados del siglo II a. E. mientras que los más recientes perduran hasta comienzos del Principado, si bien algunos de los que se ha propuesto datar en fechas avanzadas como el siglo II d. E. podrían no ser marcas grafemáticas, aunque alguno como el de Cascante, de lengua no bien identificada, parece claramente fechable a fines del siglo I d. E. ${ }^{30}$

Uno de los problemas más graves que afronta la epigrafía celtibérica es la reciente proliferación de piezas falsas, en particular de téseras de hospitalidad, hasta el punto de que resulta difícil discriminar en muchos casos si el epígrafe es genuino o falso (Beltrán, Jordán y Simón 2009).

30 Sobre los grafitos sobre cerámica véase la síntesis de Jordán 2019, 356-357. 


\subsection{Problemas relativos a los sistemas de escritura}

\subsubsection{Signario paleohispánico}

Una vez establecido por Villar que el uso de san y sigma del signario paleohispánico por parte de los celtíberos no era aleatorio, ${ }^{31}$ buena parte de los esfuerzos de la paleohispanística moderna se ha centrado en determinar qué representaba la sigma. Se tiende a pensar en la actualidad que es un signo polivalente que indicaría diferentes sonidos fruto, tal y como acaba de señalarse, de la evolución de las oclusivas dentales sonoras y quizá sordas (e incluso las velares sonoras) proto-celtas.

La aparición de la fálera de Armuña de Tajuña (Velaza e. p.) exige una reconsideración no solo de lo que estábamos empezando a suponer del uso del sistema dual en celtibérico, sino también de lo que pensábamos estaba bien establecido sobre el proceso de adopción y adaptación del signario paleohispánico en general. En efecto, la pieza parece cuando menos de finales del siglo III a. E., está escrita en la variante oriental y es dual. Debemos volver a preguntarnos, pues, ¿ ¿cuándo, dónde y cómo aprendieron a escribir los celtíberos? (sobre esta cuestión, Jordán 2019, 73-94).

\subsubsection{Alfabeto latino}

A pesar de lo poco testimoniada que está la s marcada, creada por los celtíberos en su uso del alfabeto latino, parece que de manera general viene a tener el mismo uso que la sigma en el signario paleohispánico. De momento, se ha optado por transcribirla como $\hat{S}$.

Se ha detectado la presencia de este signo con seguridad al menos en otras tres inscripciones y muy probablemente en otras dos, dentro del continuum epigráfico-lingüístico celtibérico, pero en zona occidental y lengua latina. Se trata de: el Bronce de Peralejo (Soria); la estela funeraria de Buenafuente del Sistal (Guadalajara); la estela funeraria de Almadrones (Guadalajara); y dos inscripciones funerarias de Lara de los Infantes (Burgos) (Simón y Jordán 2019).

Estamos hablando de cinco documentos datables entre los siglos I y, quizá, II d. E., es decir, no muy alejados en el tiempo de los testimonios de Peñalba y Novallas. Se localizan en la zona occidental de uso del signario celtibérico, frente a los dos documentos en lengua celtibérica que pertenecen

\footnotetext{
$31 \quad$ Villar 1993; 1995; 1996.
} 
a la zona oriental. Llama la atención, no obstante, la repartición periférica de casi todos los hallazgos con respecto a la zona celtibérica epigráfica en signario paleohispánico, excepto el caso, quizá, del Bronce de Novallas. Esta distribución no parece invitar a pensar en un caso de desarrollos epigráficos paralelos e independientes precisamente. En conjunto, aparecen sobre tres tipos de soporte: metal (bronce), piedra preparada para ser inscrita y roca (pared). La tipología textual es también variada: documentos jurídicos, documentos funerarios y documentos votivos. Todo ello apunta a la existencia de un sistema de enseñanza de escritura estandarizado y persistente en toda la Celtiberia que comportaría maestros itinerantes, ejercicios de escritura y demás prácticas habituales en el aprendizaje de la escritura.

\subsection{Problemas de edición}

La edición y la transcripción de los textos celtibéricos disfruta de un elevado grado de normalización, aunque haya todavía aspectos que requieren acuerdo.

El sistema de transcripción más difundido, que es el utilizado en este capítulo, recurre a las minúsculas en negrita para los textos redactados en escritura paleohispánica, sin distinción alguna entre signos silábicos y alfabéticos, y a las mayúsculas para los realizados en alfabeto latino: por ejemplo, lubos alizokum... [Z.00.01] y CAISAROS CECCIQ... [P.02.01], respectivamente. Se utilizan, siguiendo la propuesta de Villar, s y z para la transcripción de los signos sibilantes (Villar 1993), el segundo de los cuales J. Untermann prefería transcribir por una $ð$ (Untermann 1997). En el caso del alfabeto latino todavía debe acordarse la manera de representar la $\mathrm{S}$ marcada, que proponemos transcribir por Ś. Algunos investigadores continúan empleando sistemas de transcripción en el que se distinguen los signos silábicos y los alfabéticos, a semejanza del que empleara M. Lejeune, luPośalisoCum (Lejeune 1955), caso por ejemplo de $\mathrm{X}$. Ballester que transcribe todo el texto en mayúsculas salvo las vocales de los signos silábicos que van en minúscula, como BiCuLEI (Ballester 2008).

Respecto de los signos diacríticos hay consenso en el empleo de un trazo inferior para los signos de lectura dudosa (ㅇ) $)$ parece imponerse la crux $(+)$ para los signos de los que no puede ofrecerse lectura alguna - en vez del ${ }^{\star}$ empleado por Untermann en $M L H-y$ persiste una cierta discrepancia para la indicación de lagunas al comienzo y al final de una línea o un epígrafe entre quienes utili- 
zan solo un corchete - ] o [ según el criterio de $M L H-$ y quienes preferimos utilizar dos con tres guiones en medio ([---]) en cualquiera de las dos posiciones.

Las inscripciones escritas empleando el sistema dual o de distinción entre sonoras sordas y sonoras se transcriben en negrita cursiva (tarmeskom).

\subsection{Características de las principales ediciones}

Las inscripciones celtibéricas, además de artículos y monografías específicas, cuentan con tres ediciones generales, dos en papel y una en línea, todas ellas de elevada calidad.

Desde 1997 hasta fechas muy recientes el corpus de referencia de la epigrafía celtibérica ha sido el volumen IV de los Monumenta Linguarum Hispanicarum (Untermann 1997). Las 400 páginas consagradas en él a las inscripciones celtibéricas incluyen una exhaustiva introducción histórica, epigráfica y lingüística, dotada de mapas y tablas de signos alógrafos, listados de nombres personales y de palabras, estos ampliados en el volumen V (Wodtko 2000), así como un catálogo de 200 páginas en el que se recogen unas 110 inscripciones. Las fichas, organizadas por lugares de hallazgo, atienden a todos los aspectos epigráficos y lingüísticos, y más escuetamente al contexto arqueológico y los aspectos materiales del soporte, e incluyen fotografías y dibujos.

La excelente edición de Untermann, aunque conserve todo su valor, se ha visto, sin embargo, afectada por la notable ampliación del corpus celtibérico, multiplicado varias veces en el curso de los últimos veinte años, que ha hecho necesaria la remisión a otro catálogo más actualizado como es Hesperia. Banco de datos de lenguas paleohispánicas, un repertorio en línea desarrollado por equipos de las universidades de Barcelona, Complutense, País Vasco y Zaragoza. Las fichas, organizadas por provincias y localidades de hallazgo, ofrecen información exhaustiva y periódicamente actualizada sobre el contexto arqueológico y el soporte, una edición crítica, comentarios varios y bibliografía, y suministran también documentación gráfica y la posibilidad de generar mapas. En la actualidad cuenta con unos 250 registros, incluidas las piezas suspectae y falsae (abril 2020).

Este número de epígrafes se ha visto notablemente ampliado recientemente por la voluminosa monografía de Jordán, culminación de dos trabajos previos (Jordán 1998; 2004), en la que se presenta un exhaustivo tratamiento de la lengua celtibérica y se recogen más de 550 epígrafes, incluidos varios centenares de grafitos breves sobre cerámica (Jordán 2019). La catalogación, 
a diferencia de las dos anteriores, no se organiza según criterios geográficos sino por una combinación de criterios relativos a la escritura, el soporte y la función de los epígrafes. No todas las inscripciones están ilustradas, pero por lo demás ofrecen todos los datos propios de una edición crítica, excepto en el caso de los grafitos sobre cerámica y otros epígrafes menores.

\section{$\begin{array}{llllllllllll}\mathbf{B} & \mathbf{I} & \mathbf{B} & \mathbf{L} & \mathbf{I} & \mathbf{O} & \mathbf{G} & \mathbf{R} & \mathbf{A} & \mathbf{F} & \mathbf{I} & \mathbf{A}\end{array}$}

Ballester 2008: X. Ballester, “Post-scriptum a la plúmbea carta celtibérica a ¿Abulos?”, SEBarc 6, 2008, 69-72.

Beltrán y Tovar 1982: A. Beltrán y A. Tovar, Contrebia Belaisca I. El bronce con alfabeto 'ibérico' de Botorrita, Zaragoza 1982.

Beltrán 1989: F. Beltrán, "Los celtíberos y su historia”, en: M. C. Blasco (ed.), Los celtas en el valle medio del Ebro, Zaragoza 1989, 131-158.

Beltrán 1992: F. Beltrán, “Parentesco y ciudad en la Céltica hispana”, DHA 18, 1992, 189-220.

Beltrán 1999: F. Beltrán, "Inscripciones sobre bronce: ¿un rasgo característico de la cultura epigráfica de las ciudades hispanas?", en: XI Congresso Internazionale di Epigrafia Greca e Latina, II, Roma 1999, 21-37.

Beltrán 2001: F. Beltrán, "La hospitalidad celtibérica: una aproximación desde la epigrafía latina", PalHisp 1, 2001, 35-62

Beltrán 2004a: F. Beltrán, “"Nos Celtis genitos et ex Hiberis”. Apuntes sobre las identidades colectivas en Celtiberia", en: G. Cruz Andreotti y B. Mora Serrano (eds.), Identidades étnicas - Identidades políticas en el mundo prerromano hispano, Málaga 2004, 87-145.

Beltrán 2004b: F. Beltrán, “Imagen y escritura en la moneda hispánica”, en: F. Chaves y F. J. García (eds.), Moneta qua scripta. La moneda como soporte de la escritura [Anejos de AEspA 33], Sevilla 2004, 125-139.

Beltrán 2005: F. Beltrán, "Cultura escrita, epigrafía y ciudad en el ámbito paleohispánico", PalHisp 5, 2005, 21-56.

Beltrán 2010a: F. Beltrán, "El hospitium celtibérico", en: F. Burillo (ed.), VI simposio sobre los celtíberos. Ritos y mitos, Zaragoza 2010, 273-289.

Beltrán 2010b: F. Beltrán, "El nacimiento de un tipo epigráfico provincial: las tábulas de hospitalidad y patronato", ZPE 175, 2010, 273-286.

Beltrán 2011: F. Beltrán, "Lengua e identidad en la Hispania romana”, PalHisp 11, 2011, 19-59.

Beltrán 2012a: F. Beltrán, "Roma y la epigrafía ibérica sobre piedra del nordeste peninsular", PalHisp 12, 2012, 9-30.

Beltrán 2012b: F. Beltrán, "Hospitium municipal y ciuitas honoraria. Una relectura de la tésera de hospitalidad de Herrera de Pisuerga”, ZPE 181, 2012, 245-259.

Beltrán 2018: F. Beltrán, "Reflexiones sobre el nacimiento de la epigrafía pública en Hispania. ¿Un fenómeno de matriz romana o respuesta a una tendencia general mediterránea?", en: F. Beltrán y B. Díaz (eds.), El nacimiento de las culturas epigráficas en el Occidente mediterráneo: modelos romanos y desarrollos locales (II-I a. E.), Madrid, 157-168. 
Beltrán et al. 2013: F. Beltrán, J. J. Bienes, J. A. Hernández Vera y C. Jordán, “El bronce celtibérico en alfabeto latino de Novallas (Zaragoza). Avance", PalHisp 13, 2013, 595-613.

Beltrán et al. 2020.: F. Beltrán, B. Díaz, C. Jordán, e I. Simón, “Tesseram conferre. Etruscan, Greek, Latin, and Celtiberian tesserae hospitals", Historia 69/4, 2020, 482-518.

Beltrán, De Hoz y Untermann 1996: F. Beltrán, J. de Hoz y J. Untermann, El tercer bronce de Botorrita (Contrebia Belaisca), Zaragoza 1996.

Beltrán y Jordán 2008: F. Beltrán y C. Jordán, "La epigrafía pública celtibérica”, en: J. J. Justel, J. P. Vita y J. Á. Zamora (eds.), Las culturas del Próximo Oriente Antiguo y su expansión mediterránea, Zaragoza 2008, 289-320.

Beltrán y Jordán 2016: F. Beltrán y C. Jordán, Celtibérico. Lengua. Escritura. Epigrafía [AELAW Booklets], Zaragoza 2016.

Beltrán y Jordán 2019: F. Beltrán y C. Jordán, "Writing and language in Celtiberia”, en: A. G. Sinner y J. Velaza (eds.), Palaeohispanican Languages and Epigraphies, Oxford 2019, 240-303.

Beltrán, Jordán y Marco 2005: F. Beltrán, C. Jordán y F. Marco, "Novedades epigráficas en Peñalba de Villastar (Teruel)", PalHisp 5, 2005, 911-956.

Beltrán, Jordán y Simón 2009: "Revisión y balance del corpus de téseras celtibéricas”, PalHisp 9, 2009, 625-668.

Beltrán, Jordán y Simón e. p.: F. Beltrán, C. Jordán e I. Simón, “The inscriptions on pottery of Hispania Citerior $\left(2^{\text {nd }}-1^{\text {st }}\right.$ centuries BCE). A case study: the spindle whorls", en: W. Broekaert, E. Dupraz, A. Delattre, M. J. Estarán (ed.), Epigraphy on ceramics. The instrumentum domesticum, its textual genres and its functions in ancient societies, Genève en prensa.

Burillo 2003: F. Burillo, “Grafitos procedentes de Segeda I, Área 3”, PalHisp 3, 2003, 205-244.

Burillo 2007: F. Burillo, Los celtíberos. Etnias y estados, Barcelona 2007.

Chaín y Torre 2005: A. Chaín y J. I. Torre (eds.), Celtíberos: tras la estela de Numancia, Soria 2005.

Cowgill 1975: W. Cowgill, “The Origins of the Insular Celtic Conjunct and Absolut Verbal Endings", en: H. Rix et al. (eds.), Flexion und Wortbildung: Akten Der V. Fachtagung Der Indogermanischen Gesellschaft, Regensburg, 9. Bis 14. September 1973, Wiesbaden 1975, 40-70.

Cunliffe y Koch 2010: B. Cunliffe y J. T. Koch (eds.), Celtic from the West. Alternative Perspectives from Archaeology, Genetics, Language and Literature, Oxford 2010.

De Bernardo 1993: P. de Bernardo-Stempel, P. 1993. "Probleme der relativen Chronologie: nochmals zu idg. ${ }^{*}-\bar{o}$ im Keltischen” en: M. Rockel y S. Zimmer (eds.) Akten des ersten Symposiums deutschsprachiger Keltologen. Gosen bei Berlin, April 1992, Tübingen 1993, 37-56.

De Bernardo 2002: P. de Benardo-Stempel, “Centro y áreas laterales: la formación del celtibérico sobre el fondo del celta peninsular hispano", PalHisp 2, 2002, 89-132.

De Bernardo 2003: P. de Benardo-Stempel, "Der Beitrag des Keltischen zur Rekonstruktion des Indogermanischen Nomens", en: E. Tichy, D. S. Wodtko y B. Irslinger (eds.), Indogermanisches Nomen. Derivation, Flexion und Ablaut. Akten der Arbeitstagung der Indogermanischen Gesellschaft. Freiburg, 19. bis 22. September 2001, Bremen 2003, 31-50.

De Bernardo 2006: P. de Bernardo-Stempel, "Las lenguas célticas en la investigación: cuatro observaciones metodológicas", $C F C(G)$ 16, 2006, 5-21.

De Bernardo 2007a: P. de Benardo-Stempel, "Le declinazioni nel celtico continentale: innovazioni comuni al gallico e al goidelico?”, en: P.-Y. Lambert y G. J. Pinault (eds.), Gaulois et Celtique Continental (Clermont-Ferrand 13-16 Mai 1998), Genève 2007, 145-179. 
De Bernardo 2007b: P. de Bernardo-Stempel, "Varietäten des Keltischen auf der Iberischen Halbinsel: Neue Evidenzen”, en: H. Birkhan, (ed.), Kelten-Einfälle an der Donau. Akten des Vierten Symposiums deutschsprachiger Keltologinnen und Keltologen (Linz/Donau, 17.-21. Juli 2005), Wien 2007, 149-162.

De Bernardo 2011: P. de Bernardo-Stempel, "El genitivo-ablativo singular del indoeuropeo arcaico: viejas y nuevas continuaciones célticas", $C F C(G)$ 21, 2011, 19-43.

De Bernardo 2013: P. de Bernardo-Stempel, "From Indo-European to the Individual Celtic Languages”, en: D. Ó Baoill, D. Ó hAodha y N. Ó Muraíle (eds.), Saltair saíochta, sanasaíochta agus seanchais: a Festschrift for Gearóid Mac Eoin, Dublin 2013, 25-42.

Eska 1988: J. F. Eska, “The origin of the hispano-celtic $o$-stem genitive singular in -o and related matters", ÉC 25, 1988, 117-122.

Eska 1989: J. F. Eska, “Italic e/iste, hispano-celtic iśTe”, Em 57, 1989, 317-323.

Eska 1995: J. F. Eska, "Observations on the Thematic Genitive Singular in Lepontic and Hispano-Celtic", en: J. F. Eska, R. Geraint Gruffydd y N. Jacobs (eds.), Hispano-GalloBrittonica. Essays presented to Professor D. Ellis Evans on the Occasion of his Sixty-Fifth Birthday, Cardiff 1995, 33-46.

Eska y Wallace 2001: J. F. Eska y R. Wallace, "Remarks on the thematic genitive singular in ancient Italy and related matters", ILing 24, 2001, 77-97.

Estarán 2016: M. J. Estarán, Epigrafía bilingüe del Occidente romano. El latín y las lenguas locales en las inscripciones bilingües y mixtas, Zaragoza 2016.

Ferrer 2005: J. Ferrer, "Novetats sobre el sistema dual de diferenciació gráfica de les oclusives sordes i sonores", PalHisp 5, 2005, 957-982.

Ferrer 2014: J. Ferrer, "Ibèric kutu i els abecedaris ibèrics", Veleia 31, 2014, 227-259.

Ferrer 2017: J. Ferrer, "El origen dual de las escrituras paleohispánicas: un nuevo modelo genealógico", PalHisp 17, 2017, 55-94.

García-Bellido 1999: M. P. García-Bellido, "Notas numismáticas sobre los berones y su territorio", en: F. Villar y F. Beltrán (eds.), Pueblos, Lenguas y Escrituras en la Hispania Prerromana. Actas del VII Coloquio sobre Lenguas y Culturas Paleohispánicas (Zaragoza, 12 a 15 de Marzo de 1997), Salamanca 1999, 203-220.

Gómez-Moreno 1925: M. Gómez-Moreno, “Sobre los iberos: el bronce de Áscoli”, en: Homenaje a Ramon Menéndez Pidal, III, Madrid 1925 [= Gómez-Moreno 1949, 233-256].

Gómez-Moreno 1949: M. Gómez-Moreno, Misceláneas. Historia, Arte, Arqueología. I. Antigüedad, Madrid 1949.

Gorrochategui 1994: J. Gorrochategui, “El celtibérico, dialecto arcaico celta” Em 62, 1994, 297-324.

Gorrochategui e. p.: J. Gorrochategui, Vascónico-aquitano. Lengua, escritura, epigrafía., Zaragoza en prensa.

Hamp 1971: E. Hamp, “Fils' et 'fille' en italique. Nouvelle contribution”, BSL 66/1, 213-227.

Hesperia: $\langle$ http://hesperia.ucm.es $>$

Isaac 2002: G. R. Isaac, "The Celtiberian Alphabetic Signs San and Sigma and the Ablative Singular", Studia Celt. 36, 2002, 1-20.

Jordán 1998: C. Jordán Cólera, Introducción al celtibérico, Zaragoza.

Jordán 2004: C. Jordán Cólera, Celtibérico, Zaragoza 2004.

Jordán 2005: C. Jordán Cólera, “¿Sistema dual de escritura en celtibérico?”, PalHisp 5, 2005, 1013-1030.

Jordán 2014a: C. Jordán Cólera, "La forma verbal CABINT del bronce celtibérico de Novallas (Zaragoza), Em 82, 2014, 327-343. 
Jordán 2014b: C. Jordán Cólera, "Sobre el verbo 'dar' en celtibérico", en: A. Duplá, M. V. Escribano, L. Sancho y M. A. Villacampa (eds.), Miscelánea de Estudios en homenaje a Guillermo Fatás Cabeza, Zaragoza 2014, 429-434.

Jordán 2015: C. Jordán Cólera, “Audintum, una nueva forma verbal en celtibérico y sus posibles relaciones paradigmáticas (auzeti, auzanto, auz, auzimei, auzares...)”, $C F C(G) 25,2015$, 11-23.

Jordán 2017: C. Jordán Cólera, "Sistema dual y redundante en celtibérico", PalHisp 17, 2017, 315-327.

Jordán 2018: C. Jordán Cólera, "Los bronces celtibéricos”, en: F. Beltrán y B. Díaz (eds.), El nacimiento de las culturas epigráficas en el occidente mediterráneo. Modelos romanos y desarrollos locales (III-I a. E.), Madrid 2018, 195-230.

Jordán 2019: C. Jordán Cólera, Lengua y epigrafía celtibéricas, Zaragoza 2019.

Koch 1992: J. T. Koch, "Gallo-Brittonic vs. Insular Celtic: the relationships of the Celtic languages reconsidered", en: Gw. le Menn y J. Y. Le Moing, Bretagne et pays celtiques. Mélanges offerts à la memoire de Léon Fleuriot, Saint Brieuc-Rennes 1992, 471-495.

Koch 2009: J. T. Koch, Tartessian. Celtic in the Southwest at the Dawn of History, Aberystwith 2009.

Kruta 1991: W. Kruta (ed.), I Celti. La prima Europa, Venezia 1991.

Labeaga y Untermann 1993: J. C. Labeaga y J. Untermann, "Las téseras del poblado prerromano de La Custodia, Viana (Navarra). Descripción, epigrafía y lingüística”, TrabNavarra 11, 1993, 45-53.

Lejeune 1955: M. Lejeune, Celtiberica, Salamanca 1955.

Lorrio 2005: A. Lorrio, Los celtíberos, Madrid 2005.

Maluquer 1968: J. Maluquer, Epigrafía prelatina de la península ibérica, Barcelona 1968.

McCone 1996: K. McCone, Towards a relative Chronology of ancient and medieval Celtic Sound Change, Maynooth 1996.

McCone 2001: K. McCone, “Celtibérico, celta continental y celta común”, en: F. Villar y M. P. Fernández (eds.), Religión, Lengua y Cultura Prerromanas de Hispania. Actas del VIII Coloquio sobre Lenguas y Culturas Prerromanas de la península ibérica (Salamanca, 11-15 de mayo de 1999), Salamanca 2001, 483-494.

MLH IV: J. Untermann, Monumenta Linguarum Hispanicarum IV. Die tartessischen, keltiberischen und lusitanischen Inschriften, Wiesbaden 1997 [= Untermann 1997].

Moncunill y Velaza 2016: N. Moncunill y J. Velaza, Ibérico. Lengua, escritura, epigrafía., Zaragoza 2016.

Mullen y Ruiz Darasse 2018: A. Mullen y C. Ruiz Darasse, Gaulish. Language, writing, epigraphy, Zaragoza 2018.

Navarro y Ramírez 2003: M. Navarro y J. L. Ramírez (eds.), Atlas antroponímico de la Lusitania romana, Mérida-Burdeos 2003.

Pelegrín 2005: J. Pelegrín, “Polibio, Fabio Píctor y el origen del etnónimo “celtíberos"”, Gerión 23, 2005, 115-136.

Prag 2013: J. R. W. Prag, "Epigrapgy in the Western Mediterranean: a Hellenistic Phenomenon", en: J. R. W. Prag y J. C. Quinn (eds.), The Hellenistic West. Rethinking the Ancient Mediterranean, Cambridge 2013, 320-347.

Prosdocimi 1991: A.L. Prosdocimi, "Note sul celtico in Italia”, SE 57, 1991, 139-177. 
Francisco Beltrán Lloris | Carlos Jordán Cólera

Prósper 2005: B. M. Prósper “Estudios sobre la fonética y la morfología de la lengua celtibérica”, en: F. Villar y B. M. Prósper, Vascos, celtas e indoeuropeos. Genes y lenguas, Salamanca 2005, 153-364.

Prósper 2008: B. M. Prósper, El bronce celtibérico de Botorrita I, Pisa-Roma 2008.

Prósper 2011: B. M. Prósper, "The instrumental case in the thematic noun inflection of Continental Celtic”, HS 124, 2011, 224-241.

Prósper 2015: B. M. Prósper, “Time for Celtiberian dialectology: Celtiberian syllabic structure and the interpretation of the bronze tablet from Torrijo del Campo, Teruel (Spain)", KF 6, 2013-2014 [2015], 115-155.

Ripollès, Cores y Gozalbes 2009: P. P. Ripollès, G. Cores y M. Gozalbes, "El tesoro de Armuña de Tajuña (Guadalajara). Parte I: las monedas”, en: A. Arévalo (ed.), Actas XIII Congreso Nacional de Numismática. Moneda y Arqueología. Tomo I. Cádiz, 22-24 de octubre de 2007, Madrid-Cádiz 2009, 163-182.

Rodríguez y Diez 2014: P. Rodríguez y E. Diez, "Nueva inscripción celtibérica en piedra de El Pueyo de Belchite (Zaragoza)", PalHisp 14, 2014, 245-262.

Rodríguez y Diez 2018: P. Rodríguez y E. Diez, “Epigrafía paleohispánica en El Pueyo de Belchite (Zaragoza): Nueva inscripción celtibérica en piedra”, PalHisp 18, 2018, 189-201.

Rubio 2001: F. Rubio, "Las formas secundarias en -ko- del celtibérico", en: F. Villar y M. P. Fernández (eds.), Religión, Lengua y Cultura Prerromanas de Hispania. Actas del VIII Coloquio sobre Lenguas y Culturas Prerromanas de la península ibérica (Salamanca, 11-15 de mayo de 1999), Salamanca 2001, 581-594.

Rubio 2013: F. Rubio, "Hacia la identificación de paradigmas verbales en las inscripciones celtibéricas", PalHisp 13, 2013, 699-715.

Schmidt 1976: K. H. Schmidt, "Historisch-vergleichende Analyse des der keltiberischen Inschrift von Botorrita zu Grunde liegenden Morpheminventars", en: A. Morpurgo y W. Meid (eds.), Studies in Greek, Italic, and Indo-European Linguistics. Offered to L.R. Palmer. On the Occasion of his Seventieth Birthday, Innsbruck 1976, 359-371.

Schmidt 1977a: K. H. Schmidt, “Zum Problem des Genitivs der $o$-Stämme im Baltischen und Slavischen", en: Commentationes Linguisticae et Philologicae E. Dickenmann, Heidelberg 1977, 335-344.

Schmidt 1977b: K. H. Schmidt, Die festlandkeltischen Sprachen, Innsbruck 1977.

Schmidt 1980: K. H. Schmidt, "Continental Celtic as an Aid to the Reconstruction of ProtoCeltic”, HS 94/1, 1980, 172-197.

Schmidt 1986: K. H. Schmidt, "Zur Rekonstruktion des Keltischen. Festlandkeltisches und inselkeltisches Verbum”, ZCPh 41, 1986, 159-179.

Schmidt 1988a: K. H. Schmidt, “On the Reconstruction of Proto-Celtic", en: G. W. MacLennan (ed.), Proceedings of 1st North American Congress of Celtic Studies, Ottawa 1988, 231-248.

Schmidt 1988b: K. H. Schmidt, “Zu den phonologischen Differenzierungsmerkmalen in den keltischen Sprachen”, SCJ 1, 1988, 1-12.

Schmidt 1991: K. H. Schmidt, "Review of Études Celtiques XXV”, ZCPh 44, 1991, 363-365.

Schmidt 2001: K. H. Schmidt, "The Contribution of Celtiberian to the Reconstruction of Common Celtic: Instalment II”, en: F. Villar y M. P. Fernández (eds.), Religión, Lengua y Cultura Prerromanas de Hispania. Actas del VIII Coloquio sobre Lenguas y Culturas Prerromanas de la península ibérica (Salamanca, 11-15 de mayo de 1999), Salamanca 2001, 595-611.

Schrijver 1995: P. Schrijver, Studies in British Celtic historical phonology, Amsterdam-Atlanta 1995. 
Schrijver 2015: P. Schrijver, "Pruners and Trainers of the Celtic Family tree: The Rise and Development of Celtic in the Light of Language Contact", en: L. Breatnach, D. McManus, R. Ó hUiginn y K. Simms (eds), An XIV Comhdháil Idirnáisiúnta sa Léann Ceilteach, Maigh Nuad 2011: imeachtai = Proceedings of the XIV International Congress of Celtic Studies, held in Maynooth University, 1-5 August 2011, Dublin, Dublin 2015, 191-219.

Simón 2012: I. Simón, "La letra Q y los genitivos de plural de las llamadas 'unidades organizativas", Gerión 30, 2012, 133-147.

Simón 2013: I. Simón, Los soportes de la epigrafía paleohispánica. Inscripciones sobre piedra, bronce y cerámica, Zaragoza-Sevilla 2013.

Simón 2014: I. Simón, “Inscripciones celtibéricas en alfabeto latino”, en F. Burillo y M. Chordá (eds.), VII Simposio sobre los celtíberos. Nuevos Hallazgos, Nuevas Interpretaciones, Teruel 2014, 493-500.

Simón 2019: I. Simón, "Sobre la inscripción del mosaico helenístico de Ilici (La Alcudia, Elche)", PalHisp 19, 2019, 123-144.

Simón y Gorrochategui 2018: I. Simón y J. Gorrochategui, "Estela con iconografía e inscripción celtibéricas procedente de Clunia”, AEspA 91, 2018, 55-66.

Simón y Jordán 2018: I. Simón y C. Jordán, “The Celtiberian S. A New Sign in (Paleo)Hispanic Epigraphy", Tyche 33, 2018, 183-205.

Sims-Williams 2007: P. Sims-Williams, "Common Celtic, Gallo-Brittonica and Insular Celtic", en: P.-Y. Lambert y G. J. Pinault (eds.), Gaulois et Celtique Continental (Clermont-Ferrand 13-16 Mai 1998), Genève 2007, 309-354.

Sinner y Velaza 2019: A. G. Sinner y J. Velaza (eds.), Palaeohispanic Languages and Epigraphies, Oxford 2019.

Tovar 1946: A. Tovar, "Las inscripciones ibéricas y la lengua de los celtíberos", $B R A E$ 25,1946, 7-42.

Tovar 1949: A. Tovar, Estudios sobre las primitivas lenguas hispánicas, Buenos Aires 1949.

Untermann 1965: J. Untermann, Elementos de un atlas antroponímico de la Hispania Antigua, Madrid 1965.

Untermann 1967: J. Untermann, "Die Endung des Genitiv singularis der o-Stämme im Keltiberischen”, en: W. Meid (ed.), Beiträge zur Indogermanistik und Keltologie, Julius Pokorny zum 80. Geburtstag gewidmet, 281-288, Innsbruck 1967 [= J. Untermann "La terminación del genitivo singular de los temas en -o en el celtibérico: de 1965 a 1995", ELEA 3, 2000, 125-142].

Untermann 1975: J. Untermann, Monumenta Linguarum Hispanicarum I. Die Münzlegenden, Wiesbaden 1975.

Untermann 1980: J. Untermann, Trümmersprachen zwischen Grammatik und Geschichte. Opladen 1980.

Untermann 1984: J. Untermann, "Los celtíberos y sus vecinos occidentales", Lletres asturianes 13, 1984, 6-26.

Untermann 1997: J. Untermann, Monumenta Linguarum Hispanicarum IV. Die tartessischen, keltiberischen und lusitanischen Inschriften, Wiesbaden 1997.

Untermann 1999: J. Untermann, "La aportación lingüística de los antropónimos del "Bronce de Botorrita III”', en: F. Villar y F. Beltrán (eds.), Pueblos, Lenguas y Escrituras en la Hispania Prerromana. Actas del VII Coloquio sobre Lenguas y Culturas Paleohispánicas (Zaragoza, 12 a 15 de Marzo de 1997), Salamanca 1999, 635-649.

Velaza e. p.: J. Velaza, “La tésera de Armuña de Tajuña (Guadalajara)", en prensa. 
Villar 1993: F. Villar, "Las silbantes en celtibérico”, en: J. Untermann y F. Villar (eds.), Lengua y cultura en la Hispania prerromana. Actas del V Coloquio sobre Lenguas y Culturas Prerromanas de la península ibérica (Colonia, 25-28 de Noviembre de 1989), Salamanca 1993, 773-818.

Villar 1993-1995: F. Villar, "El instrumental en celtibérico”, Kalathos 13-14, 1993-1995, 325-338.

Villar 1995a: F. Villar, Estudios de celtibérico y de toponimia prerromana, Salamanca 1995.

Villar 1995b: F. Villar, "Nueva interpretación de las leyendas monetales celtibéricas", en: M. P. García-Bellido, R. M. Sobral (eds.), La moneda hispánica: ciudad y territorio. Actas del I Encuentro Peninsular de Numismática Antigua, Madrid 1995, 337-346.

Villar 1996: F. Villar, “Fonética y Morfología Celtibéricas”, en: F. Villar y J. D’Encarnação (eds.), La Hispania prerromana. Actas del VI Coloquio sobre Lenguas y Culturas Prerromanas de la península ibérica (Coimbra, 13-15 de octubre de 1994), Salamanca 1996, 339-378.

Villar 1997: F. Villar, “The Celtiberian Language”, ZCPh 49-50, 1997, 898-949.

Villar 1999: F. Villar, “Hispanocelta o celtibérico”, en: E. C. Polomé y C. F. Justus (eds.), Language Change and Typological Variation: In Honor of W. P. Lehmann on the Occasion of his 83rd Birthday, Vol. I, 60-77, [Journal of Indo-European Studies, Monograph Number 30], Washington 60-77.

Villar 2005: F. Villar, "La lengua celtibérica”, en: G. Carrasco y J. C. Oliva, Escrituras y lenguas del Mediterráneo en la antigüedad, Cuenca 2005, 307-362.

Villar et alii 2001: F. Villar, M. A. Díaz, M. Medrano y C. Jordán, El IV bronce de Botorrita (Contrebia Belaisca): Arqueología y Lingüística, Salamanca 2001.

Von Humboldt 1821: W. von Humboldt, Prüfung der Untersuchungen über die Urbewohner Hispaniens vermittelst der Vaskischen Sprache, Berlin 1821.

Watkins 1999: C. Watkins, "A Celtic Miscellany", en: Proceedings of the Tenth Annual UCLA Indo-European Conference. Los Angeles, May 21-23, 1998, Washington 1999, 3-25

Wodtko 2000: D. S. Wodtko, Monumenta Linguarum Hispanicarum V.1. Wörterbuch der keltiberischen Inschriften, Wiesbaden 2000.

Wodtko 2017: D. S. Wodtko, Lusitanian. Language, Writing, Epigraphy, Zaragoza 2017. 